Paweł LINDSTEDT, Edward ROKICKI, Maciej DELIŚ, Kamila DOBOSZ, Andrzej CZARNECKI

Air Force Institute of Technology (Instytut Techniczny Wojsk Lotniczych)

\title{
DIAGNOSTICS OF THE EXCESSIVE WEAR OF THE MACHINE ON A MODEL OF DEVELOPMENTAL, PROGRESSIVE INTERACTIONS BETWEEN DIAGNOSTIC SIGNALS AND ROTATION SPEED SIGNALS
}

\section{Diagnostyka przypadku wzmożonego zużycia maszyny bazująca na modelu rozwojowych, progresywnych inter- akcji między sygnałami zużycia i sygnałami użytkowymi}

\begin{abstract}
In the machine operating process, there are certain interactions between its operational use and wear. The current wear is increased by the current intensity of operational use, and usable potential is reduced by the current wear rate. In the diagnostic inference process, static characteristics and trajectories of state from the experiment are compared with different matrices determined for various assumed configurations of changes. As a result, the approximated diagnosis is created. This method is not universal. It applies only to the continuous progressive state, more or less increased wear rate of the machine.
\end{abstract}

Keywords: interaction equation, usable potential, wear rate, static characteristic, trajectory state, state matrix, diagnostic inference

Streszczenie: W procesie eksploatacji maszyny występuja interakcje między jej użytkowaniem a użyciem. Aktualne zużycie powiększone jest aktualna intensywnościa użytkowania, a potencjał użytkowy jest pomniejszany aktualnym stanem zużycia. W procesie wnioskowania diagnostycznego charakterystyki statyczne i trajektorie stanu z eksperymentu porównuje się z różnymi matrycami wyznaczonymi dla różnych założonych konfiguracji zmian. Efektem tego postepowania jest przybliżona diagnoza. Metoda nie jest uniwersalna. Dotyczy tylko stanu ciagłego, postęujacego, mniej lub bardziej wzmożonego zużywania się maszyny.

Słowa kluczowe: równanie interakcji, potencjał użytkowy, stan zużycia, charakterystyka statyczna, trajektoria stanu, matryca stanu, wnioskowanie diagnostyczne 


\section{Introduction}

In the machine operating process (assemblies, elements), there are two closely related phenomena: operational use (related to the quality and intensity of machine operation, requirements of its operation, intensity and quality of usage, maintenance, etc.) that generates a set of rotation speed signals $U$ and wear (connected with changes in the technical condition of the machine, damages, degradation, deterioration, wear, etc.) that generates a set of diagnostic signals $D$. These processes (operational use and wear) have a different physical nature. Thus, signals $U$ and $D$ are any physical quantities: functional, defectoscope, thermovision, vibroacoustic, i.e., determined and probabilistic. Due to this, studying the relationship between these signals is complex and is often treated in a simplified way.

In operational practice, it is often assumed that these processes are autonomous. With this assumption, the processes (phenomena) of usage (operation) and wear (diagnostic) can be described by separate (unrelated) equations of state $[1,2,5]$ :

$$
\begin{gathered}
\dot{U}=-a_{U} U \\
\dot{D}=a_{D} D
\end{gathered}
$$

where:

$U, \dot{U}$ - complex rotation speed signal (operation, functioning) and its derivative

$a_{U} \quad$ - parameter of the machine's usable potential

$D, \dot{D}$ - complex diagnostic signal (of wear and its derivative)

$a_{D} \quad$ - parameter of the wear rate (degradation) of the machine.

We cannot adopt the autonomy of wear and operational processes $[3,5,6]$. It should be mentioned that the method and intensity of machine operation has a significant impact on the speed of change of its technical condition (wear), and reversely, machine wear has an impact on its operation (possibilities of using it). The relations between the rotation speed signals $U$ and the diagnostic signals $D$ under mutually progressive (developmental, dangerous) interactions can be described by typical linear equations of state applied in automation control engineering $[2,4,5]$ :

$$
\begin{gathered}
\dot{U}=-a_{U} U-b_{U} D \\
\dot{D}=a_{D} D+b_{D} U
\end{gathered}
$$

Where additionally:

$b_{U}$ - intensity parameter of the impact of the wear state $D$ on operational state $U$

$b_{D}$ - intensity parameter of the impact of the wear state $U$ on operational state $D$.

By analyzing equations (3) and (4), it can be concluded that identification of the system described by related formulas (3) and (4) can come down to defining the determined 
relations between signals $\{D\}$ and $\{U\}$ in the form of tangential characteristics, trajectory of state as well as the values and proportions of parameters $a_{U}, b_{U}, a_{D}, b_{D}$. In this way, a necessary information to conduct the diagnosing process of a machine (assessment of degradation degree and quality of operation) will be determined.

\section{Theoretical basics for analyzing the equations of interaction}

A diagnosed machine can have different operating states. It can have a small usable potential (low value $\left|a_{U}\right|$ ); low sensitivity to usable potential (low value $\mathrm{b}_{\mathrm{U}}$ ). The object can have significant wear (high value $a_{D}$ ) and high sensitivity to operational and control conditions (high value $b_{D}$ ). There may be plenty of such combinations. Thus, the analysis of equations (3) and (4) must be extensive, complex, and deep and include the entire static and dynamic identification and actively use the elements of algebraic topology and variational calculus (combinatorics) $[1,5,7]$.

\subsection{Statical identification of the object described by the equation of progressive interaction}

The relations between signals $\mathrm{D}$ and $U$ are determined for steady states, which are characterized by the fact that derivatives $\dot{D}$ and $\dot{U}$ are zero. Relations $\mathrm{D}=\mathrm{f}(\mathrm{U})$ for steady states are presented by the static characteristics. To determine the static characteristics, equations (3) and (4) should be added by equations. This operation of variational calculus is often used to solve these problems $[1,5]$. After adding sides of the equation, the following is obtained:

$$
\dot{U}+\dot{D}=-a_{U} U-b_{U} D+a_{D} D+b_{D} U
$$

after the arrangement, we receive the following:

$$
\dot{D}+b_{U} D-a_{D} D=-a_{U} U+b_{D} U-\dot{U}
$$

After assuming $\dot{U}=0$ and $\dot{D}=0$, we have:

$$
-a_{D} D+b_{U} D=-a_{U} U+b_{D} U
$$

and further:

$$
\left(a_{D}-b_{U}\right) D=\left(a_{U}-b_{D}\right) U
$$

and finally: 


$$
D=\frac{a_{U}-b_{D}}{a_{D}-b_{U}} U
$$

After introducing $A_{U}=a_{U}-b_{D} ; A_{D}=a_{D}-b_{U}$ we obtain:

$$
D=\frac{A_{U}}{A_{D}} U
$$

Equation 10 shows that when $A_{U}$ big and $A_{D}$ small $\mathrm{A}_{\mathrm{D}}<\mathrm{A}_{\mathrm{U}}$, then static characteristics is very steep, and when $A_{U}$ small and $A_{D}$ big $A_{D} \gg A_{U}$ then characteristics is flat. For the case of $A_{U}=A_{D}$ characteristics is inclined at $45^{\circ}$. Then $\frac{A_{U}}{A_{D}}=1$. Thus, for the case $A_{U}=$ $A_{D}$, we have:

$$
a_{U}-b_{D}=a_{D}-b_{U}
$$

whereby $a_{U}>b_{D}$ i $a_{D}>b_{U}$.

And further:

$$
a_{U}+b_{U}=a_{D}+b_{D}
$$

After assuming $b_{U}=b_{D}=b$ and, we have:

$$
a_{U}=a_{D}
$$

Static characteristics based on formula (10) taking into account (11), (12), and (13) were exhibited in fig. 1.

The process of diagnostic inference can depend on testing the location of static characteristics determined from the current diagnostic test in relation to pattern characteristics (reference) (fig. 1). Thus, when $\left|A_{U}\right|$ increases, then static characteristics becomes steeper, and when $A_{D}$ increases, then it becomes flatter (11). Further, when $b_{D}$ decreases, then the characteristics will become very steep, and when $b_{U}$ decreases, then static characteristics will be flatter (9). It should be mentioned that in the examined operational state distinguished by permanent, progressive process of machine destruction, $a_{D}$ and $a_{U}$ always increase (wear rate and usage degree of usage potential are on the increase) $b_{U}$ and $b_{D}$ also increase before they reach the following state: $b_{D}=a_{U}$ i $b_{U}=a_{D}$. 


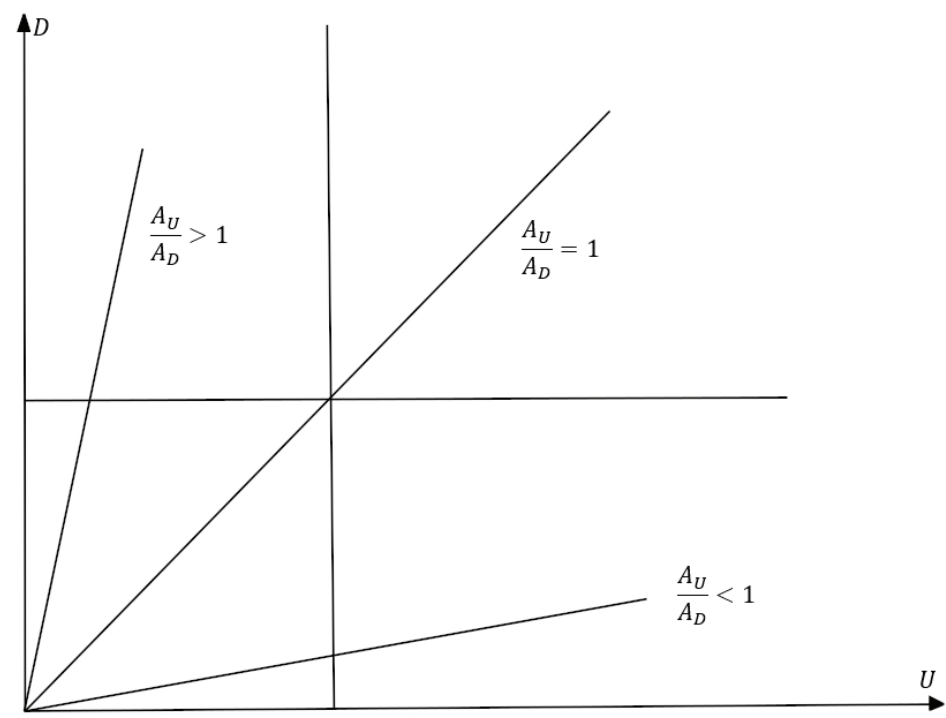

Fig. 1. Static characteristics for singular particular relations between parameters $\mathrm{a}_{\mathrm{U}}, a_{D}, b_{U}, b_{D}$ of model of the progressive interactions between diagnostic signals $D$ and usable signals $U$

\subsection{Dynamic identification of the object described by the equation of progressive interaction}

Relation between signals $D$ and $U$ can be described as a trajectory, which is obtained from equations (3) and (4) after removing time $t$ by a direct integration method [5]. Thus, Equation (5), which is a sum of Equations (3) and (4) after making certain conversions, takes the following form:

$$
\dot{U}+\dot{D}=\left(-a_{U}+b_{D}\right) U+\left(a_{D}-b_{U}\right) D
$$

The right side of the equation is converted to the form that enables us to apply a direct integration method:

$$
\dot{U}+\dot{D}=\left(-a_{U}+b_{D}\right) \frac{1}{2} \dot{U}^{2}+\left(a_{D}-b_{U}\right) \frac{1}{2} \dot{D}^{2}
$$

After integration, we obtain:

$$
U+D=\frac{1}{2}\left(-a_{U}+b_{D}\right) U^{2}+\frac{1}{2}\left(a_{D}-b_{U}\right) D^{2}
$$

Equation (16) can be converted to the following form: 


$$
-\frac{1}{2}\left(a_{D}-b_{U}\right) D^{2}+D=-\frac{1}{2}\left(a_{U}-b_{D}\right) U^{2}-U
$$

and further:

$$
\left(a_{D}-b_{U}\right) D^{2}-2 D=\left(a_{U}-b_{D}\right) U^{2}+2 U
$$

and finally, after performing substitutions, $a_{D}-b_{U}=A_{D} ; a_{U}-b_{D}=A_{U}$ we receive:

$$
A_{D} D^{2}-2 D=A_{U} U^{2}+2 U
$$

According to topology rules, a metric can be defined for the selected characteristic model states consisting of trajectories described by (19).

Equation (19) can be rewritten in different forms:

$$
\begin{gathered}
\left(A_{D} D-2\right) D=A_{U} U^{2}+2 U \\
A_{D} D^{2}-2 D=\left(A_{U} U+2\right) U \\
A_{D} D^{2}-2 D=C(U)
\end{gathered}
$$

Many exemplary trajectories are determined by different assumptions. It is adopted that $A_{D}=A_{U}=A$.

Then, from (19), we obtain the following:

$$
A D^{2}-2 D=\mathrm{A} U^{2}+2 U
$$

After conversions (20), the following is received:

$$
\begin{gathered}
A\left(D^{2}-U^{2}\right)=2 D+2 U \\
A(D-U)(D+U)=2(D+U) \\
D-U=\frac{2}{A}
\end{gathered}
$$




$$
D=\frac{2}{A}+U
$$

Additionally, when it is assumed that $A_{D}=A_{U}=A=2$, then:

$$
D=1+U
$$

It can be adopted that $A>2$, and next $A<2$. After that, a set of straight lines parallel to the straight line described by (23) is obtained from (22). The question arises what is the relation between $D=f(U)$ for $U=0$.

From equation (19a), we get:

$$
\left(A_{D} D-2\right) D=0
$$

From equation (24), we obtain:

$$
D_{1}=2 \operatorname{oraz} D_{2}=0
$$

For $U>0$ equation (19c) takes the following form:

$$
A_{D} D^{2}-2 D-C(U)=0
$$

Furthermore, by using the known formulas for solving the quadratic equation:

$$
\begin{gathered}
a x^{2}+b x+c=0 \\
\Delta=b^{2}-4 a c \\
x_{1,2}=\frac{-b \pm \sqrt{\Delta}}{2 a}
\end{gathered}
$$

From (25) for every adopted $U>0,2$ radicals are determined:

$$
\begin{aligned}
& D_{1}=\frac{1}{A_{D}}\left(1+\sqrt{1+A_{D} A_{U} U^{2}+2 A_{D} U}\right) \\
& D_{2}=\frac{1}{A_{D}}\left(1-\sqrt{1+A_{D} A_{U} U^{2}+2 A_{D} U}\right)
\end{aligned}
$$

Since the experiment shows that signals $D$ and $U$ are positive, then only radical $D_{1}$ is analysed (radical $D_{2}$ is always negative). After that, additional characteristic trajectory 
points can be determined, taking into account the appropriate assumptions, e.g. that $A_{D}$ is a few times bigger than $A_{U}$, and then that $A_{U}$, is a few times bigger than $A_{D}$, and it enables to get information needed to interpret formulas (22) and (23), where the assumption $A_{D}=A_{U}$ was applied.

Therefore, it can be adopted that:

for $U=0 ; A_{U}<A_{D} ; A_{U}=0,3$, then, from equation (26) we get:

$$
D_{1}=\frac{1}{A_{D}}(1+\sqrt{1})=\frac{2}{A_{D}}
$$

for $U=0,1 ; A_{U}<A_{D} ; A_{U}=0,3$, then, from equation (26) we get:

$$
D_{1}=\frac{1}{A_{D}}\left(1+\sqrt{1+0,203 A_{D}}\right)
$$

for $U=1 ; A_{U}<A_{D} ; A_{U}=0,3$, then, from equation (26) we get:

$$
D_{1}=\frac{1}{A_{D}}\left(1+\sqrt{1+2,3 A_{D}}\right)
$$

for $U=2 ; A_{U}<A_{D} ; A_{U}=0,3$, then, from equation (26) we get:

$$
D_{1}=\frac{1}{A_{D}}\left(1+\sqrt{1+5,2 A_{D}}\right)
$$

for $U=4 ; A_{U}<A_{D} ; A_{U}=0,3$, then, from equation (26) we get:

$$
D_{1}=\frac{1}{A_{D}}\left(1+\sqrt{1+12,8 A_{D}}\right)
$$

for $U=8 ; A_{U}<A_{D} ; A_{U}=0,3$, then, from equation (26) we get:

$$
D_{1}=\frac{1}{A_{D}}\left(1+\sqrt{1+35,2 A_{D}}\right)
$$

Moreover, by assuming values for $A_{D}=1,2,4$ appropriately bigger from the value of parameter $A_{U}=0,3$ we get points of the selected, sought model reference trajectories. The points of these trajectories are presented in tab. 1 . 
Table 1

Points of reference trajectory $D=f(U)$ for different cases

\begin{tabular}{|c|c|c|c|c|c|c|}
\hline$A_{D} U$ & 0 & 0,1 & 1 & 2 & 4 & 8 \\
\hline 1 & 2 & 2,1 & 2,82 & 3,49 & 4,72 & 7,02 \\
\hline 2 & 1 & 1,1 & 1,69 & 2,19 & 3,08 & 4,73 \\
\hline 4 & 0,5 & 0,59 & 1,05 & 1,42 & 2,06 & 3,23 \\
\hline
\end{tabular}

After that, the change $D_{1}=f(U)$ is analyzed for different values $A_{U}=1,2,4$, which are appropriately bigger from $A_{D}=0,3$, so for the case when the condition $A_{U}>A_{D}$ is met by fulfilling the condition that $\mathrm{a}_{\mathrm{D}}>0 ; \mathrm{a}_{\mathrm{U}}>0$.

Therefore, it can be written that;

for $U=0 ; A_{D}<A_{U} ; A_{D}=0,3$, then from equation (26) we obtain:

$$
D_{1}=3,333(1+\sqrt{1+0})=6,666
$$

for $U=0,1 ; A_{D}<A_{U} ; A_{D}=0,3$, then from equation (26) we obtain:

$$
D_{1}=3,333\left(1+\sqrt{1,06+0,003 A_{U}}\right)
$$

for $U=1 ; A_{D}<A_{U} ; A_{D}=0,3$, then from equation (26) we obtain:

$$
D_{1}=3,333\left(1+\sqrt{1,6+0,3 A_{U}}\right)
$$

for $U=2 ; A_{D}<A_{U} ; A_{D}=0,3$, then from equation (26) we obtain::

$$
D_{1}=3,333\left(1+\sqrt{2,2+1,2 A_{U}}\right)
$$

for $U=4 ; A_{D}<A_{U} ; A_{D}=0,3$, then from equation (26) we obtain:

$$
D_{1}=3,333\left(1+\sqrt{3,4+4,8 A_{U}}\right)
$$

for $U=8 ; A_{D}<A_{U} ; A_{D}=0,3$, then from equation (26) we obtain:

$$
D_{1}=3,333\left(1+\sqrt{5,8+19,2 A_{U}}\right)
$$

Furthermore, by assuming values for $A_{U}=1,2,4$, which are appropriately bigger than parameter $A_{D}=0,3$, the points of the selected and sought model reference trajectories are received.

The points of these trajectories are presented in tab. 2 . 
Table 2

Points of reference trajectory $D=f(U) A_{U}>A_{D}=0,3$ for different cases

\begin{tabular}{|c|c|c|c|c|c|c|}
\hline$A_{U}$ & 0 & 0,1 & 1 & 2 & 4 & 8 \\
\hline 1 & 6,666 & 6,766 & 7,93 & 9,47 & 12,87 & 20,0 \\
\hline 2 & 6,666 & 6,772 & 8,27 & 10,47 & 15,37 & 25,5 \\
\hline 4 & 6,666 & 6,782 & 8,899 & 12,17 & 19,16 & 33,63 \\
\hline
\end{tabular}

Based on data from tables 1 and 2, characteristic trajectories for the solutions of equations (3) and (4) - fig. 2.

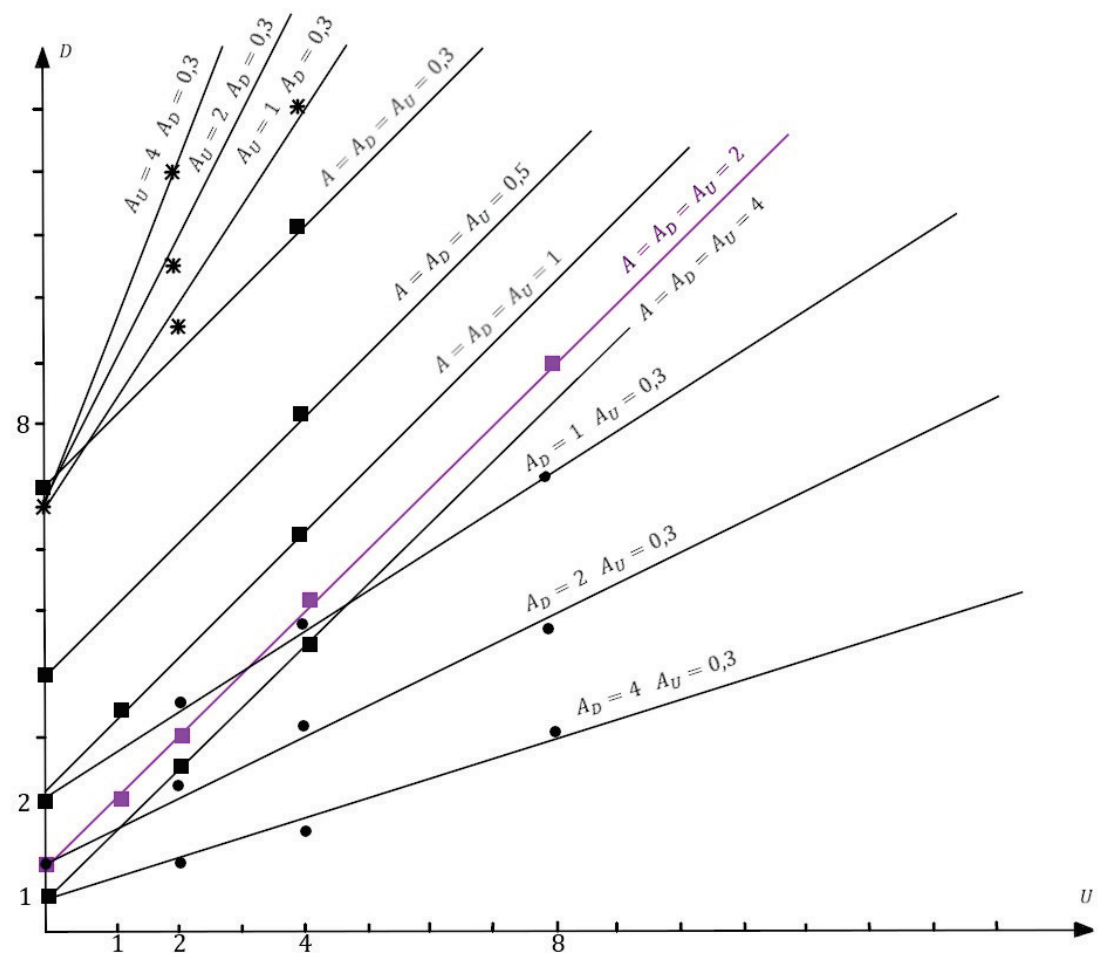

Fig. 2. Reference trajectory $D=f(U)$ for specific cases of the relations between parameters $A_{U}$ and $A_{D}: A_{U}>A_{D}, A_{U}=A_{D}, A_{U}<A_{D}$

Trajectories $D=f(U)$ (fig. 2) are different for different, including specific cases of relations between parameters $A_{U}$ and $A_{D}$. They are the bundles of steep lines, which have the common origin $\mathrm{D}=\frac{2}{\mathrm{~A}_{\mathrm{D}}}$ for $\mathrm{U}=0$, whereby $A_{D}=$ const and $A_{D}<A_{U}\left(A_{D}=\right.$ 0,$\left.3 ; A_{U}=1,2,4\right)$ or bundles of parallel lines described by equation $D=\frac{2}{A_{D}}+U$ with 
different origin $D=\frac{2}{A}$, whereby for $\mathrm{A}_{\mathrm{U}}=\mathrm{A}_{\mathrm{D}}=\mathrm{A}=2$ we obtain $\mathrm{D}=1+\mathrm{U}$ with origin $D=1$. They can also be bundles of straight lines, which have different origin, and for $U=0$ we have the value $\frac{2}{A_{D}}$ for $A_{U}=0,3$. Thus, it is visible that for $\mathrm{U}=0$ we can estimate $A_{D}$ and further also from $A_{U}$ from trajectory path, so it is possible to identify the wear of the object.

\section{Diagnostic matrix}

The diagnostic matrix is created from the virtual static characteristics and trajectories determined for the clearly identified wear mode described for it by an adjusted interaction model. Thus, the static characteristics of fig. 1 and the trajectories of fig. 2 belong to the diagnostic matrix that enables interpreting the waveforms of signals $D$ and $U$ assuming that they were defined for an excessively worn machine. The matrix can be successfully used applied in the process of diagnostic inference.

Signals $D$ (effective value) and $U$ (rev/min) were determined experimentally. They are shown in figs. $3 a, b, c, d[8]$.
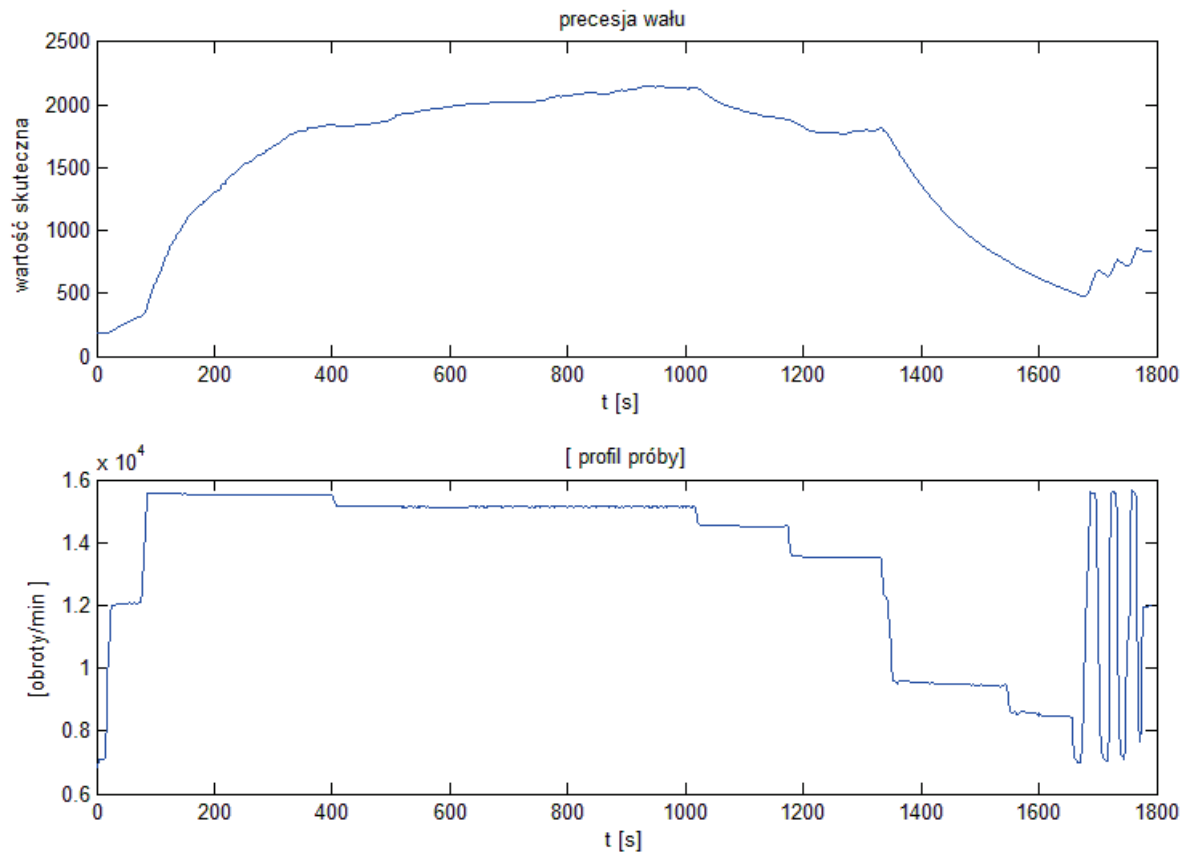

Fig. 3a. Profile of test a - measured parameters of the rotational speed of the shaft of the aircraft engine $U$ and an effective value of shaft precession $D$ in a diagnostic experiment 

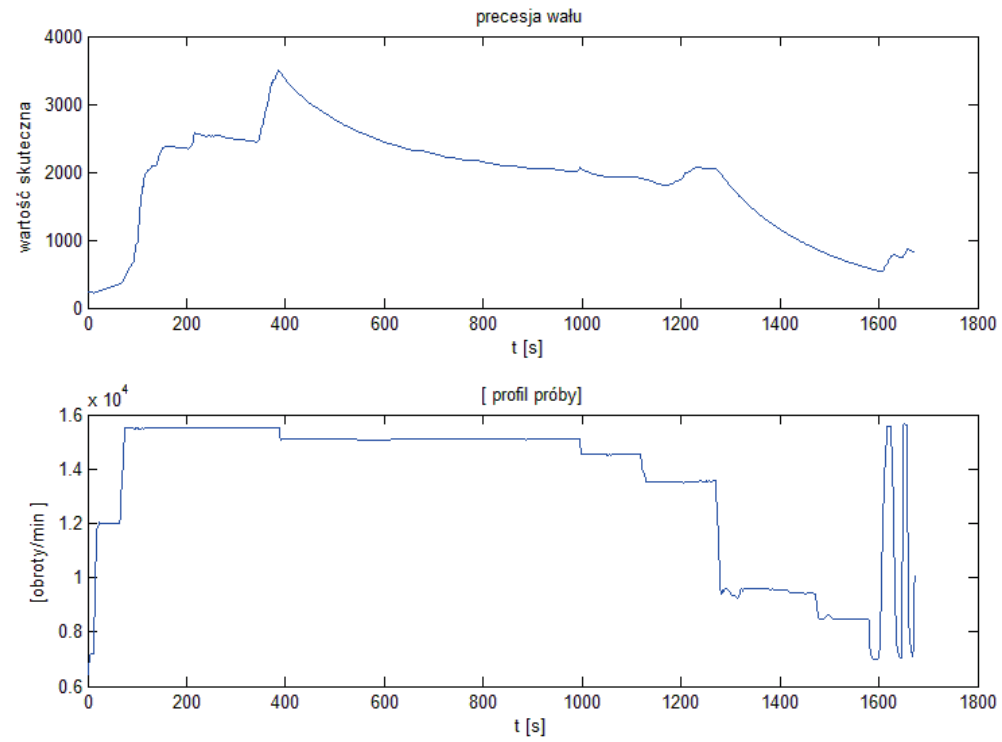

Fig. 3b. Profile of test b - measured parameters of the rotational speed of the shaft of the aircraft engine $U$ and an effective value of shaft precession $D$ in a diagnostic experiment
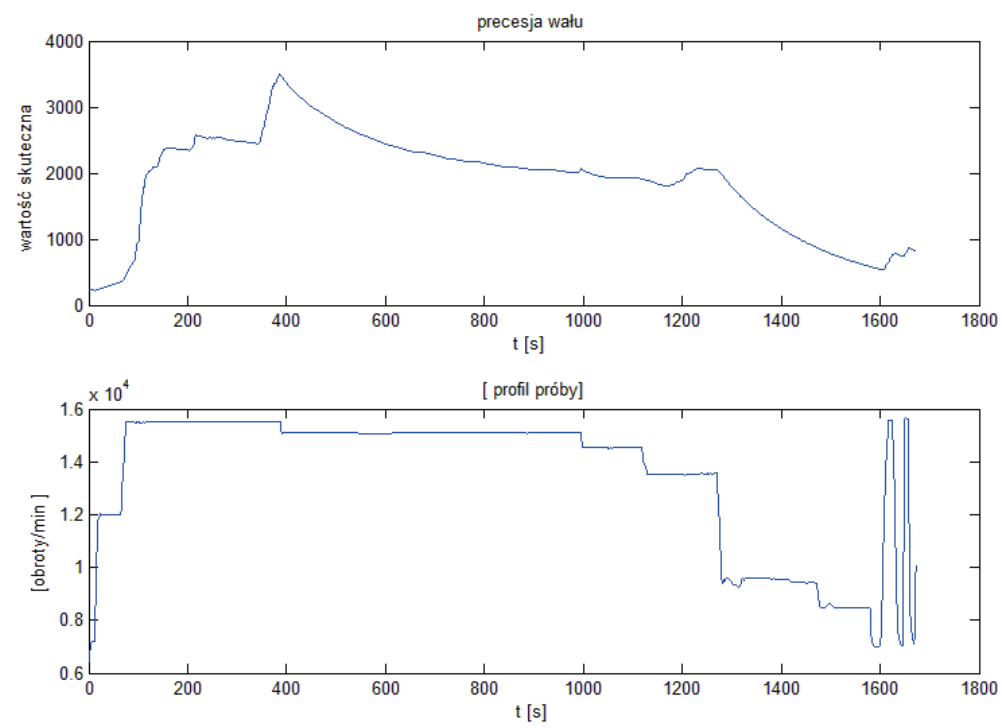

Fig. 3c. Profile of test $\mathrm{c}$ - measured parameters of the rotational speed of the shaft of the aircraft engine $U$ and an effective value of shaft precession $D$ in a diagnostic experiment 

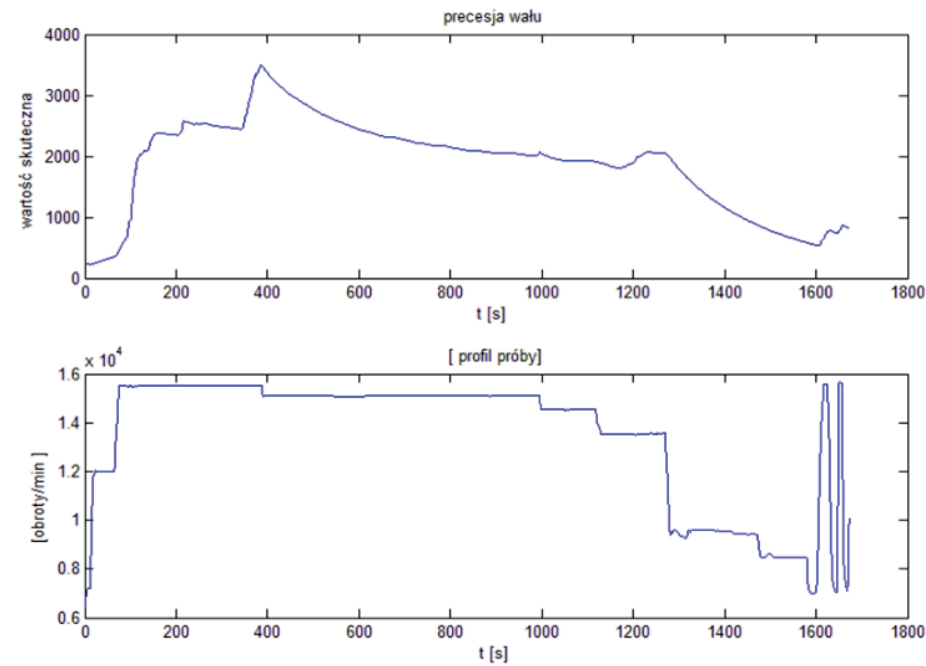

Fig. 3d. Profile of test $d$ - measured parameters of the rotational speed of the shaft of the aircraft engine $U$ and an effective value of shaft precession $D$ in a diagnostic experiment

The results of the experiment (figs. 3a, b, c, d) after time removal are shown in figs. $4 a, b, c, d$.

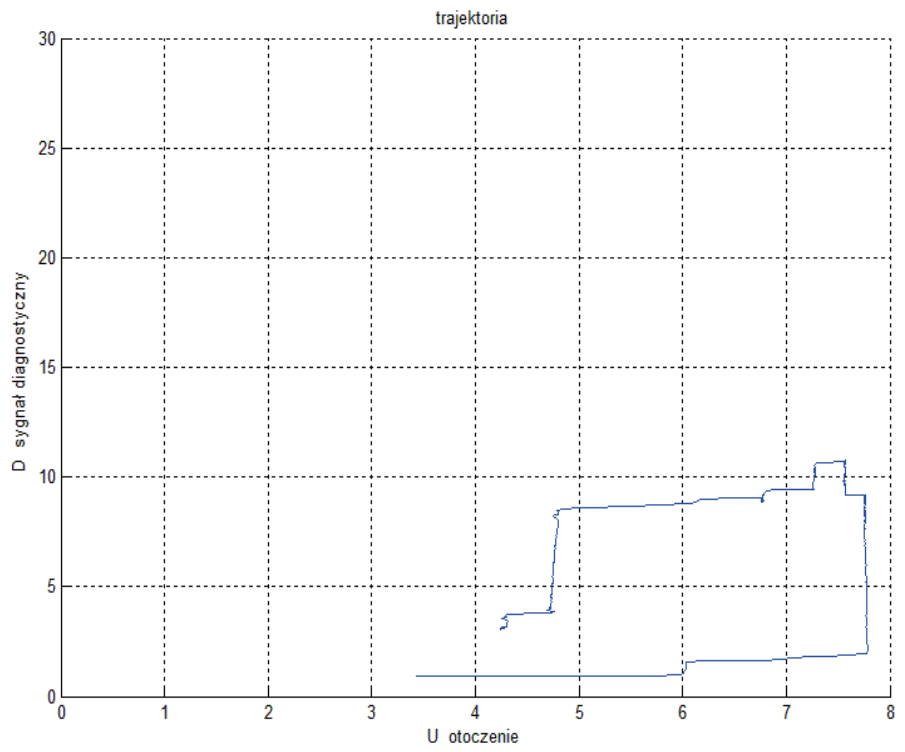

Fig. 4a. Trajectory of relation between a diagnostic signal $D$, and an ambient signal $U$ in the experiment from test a (fig. 3a) 


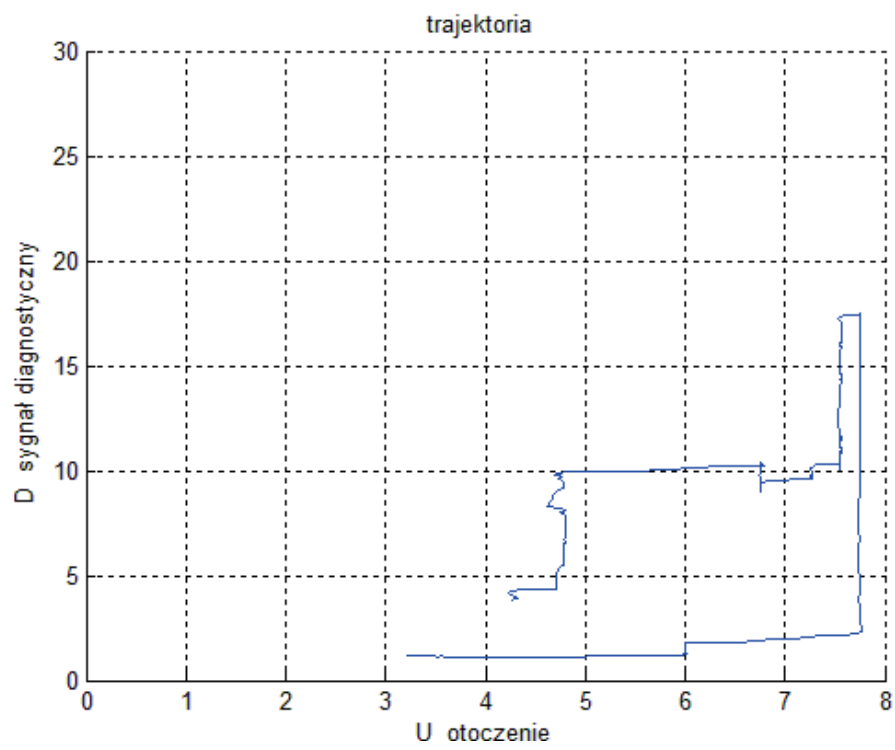

Fig. 4b. Trajectory of relation between a diagnostic signal $D$, and an ambient signal $U$ in the experiment from test $b$ (fig. $3 b$ )

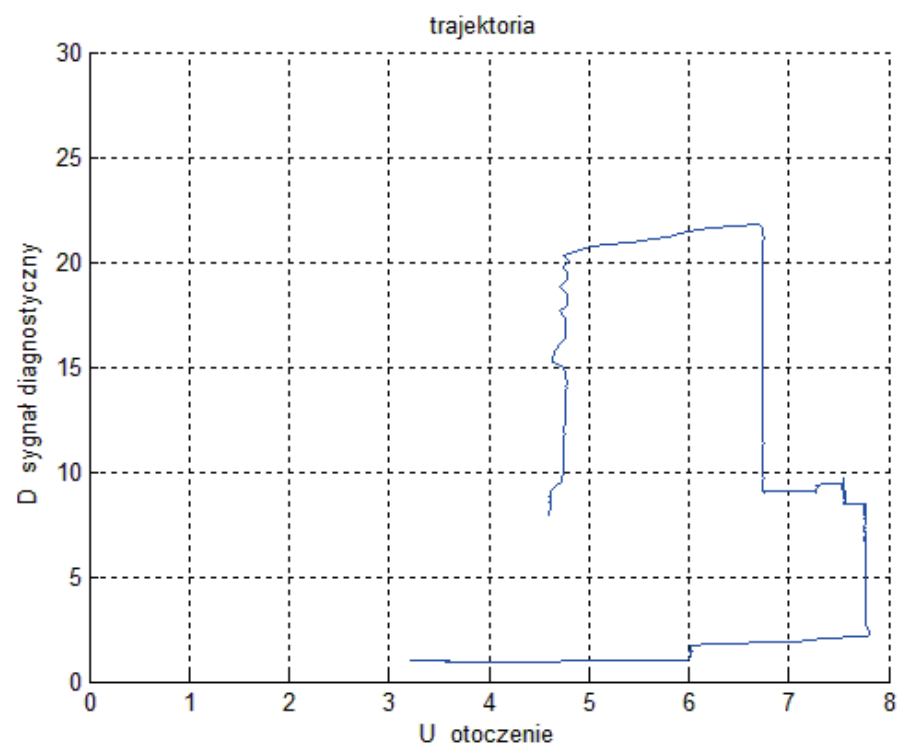

Fig. 4c. Trajectory of relation between a diagnostic signal $D$, and an ambient signal $U$ in the experiment from test $\mathrm{c}$ (fig. 3c) 


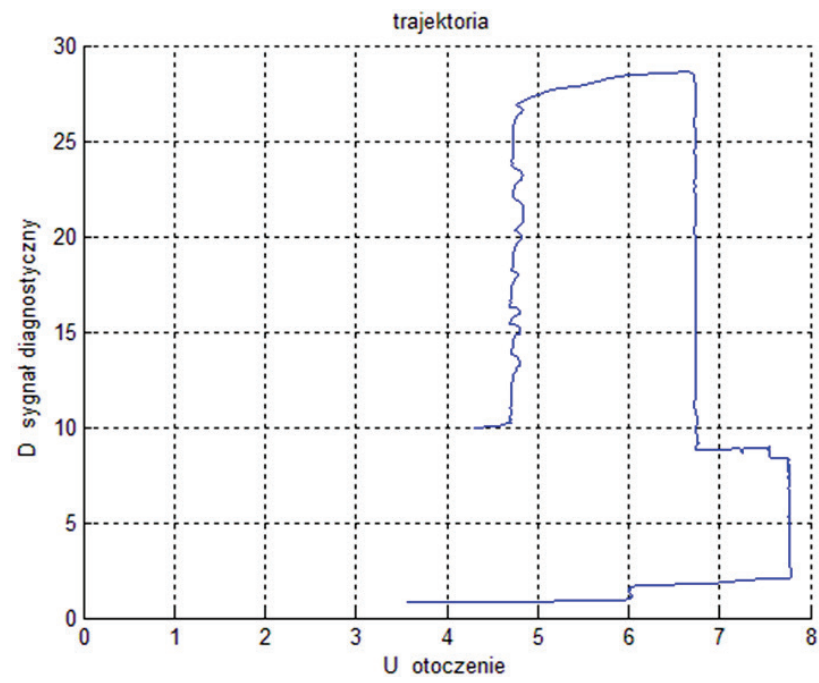

Fig. 4d. Trajectory of relation between a diagnostic signal $D$, and an ambient signal $U$ in the experiment from test $\mathrm{d}$ (fig. $3 \mathrm{~d}$ )

A scale for measuring $D$ and $U$ is extended to a signal scale, which was used in the matrix. Thus, when in figs. 3 we see that $D$ changes from $0 \div 6000$, and $U$ changes from $6 \div 1,6 * 10^{4}$, then after taking into account the matrix scale (tables 1 and 2), we obtain the following: $D$ changes from $0 \div 30$, and $U$ from $0 \div 8$. Then, the waveforms in figs. 3 and after time removal, figs. 4 takes the same form as figs. 5. They are static trajectories and characteristics, which clearly describe the steady and unsteady states of machine operation.

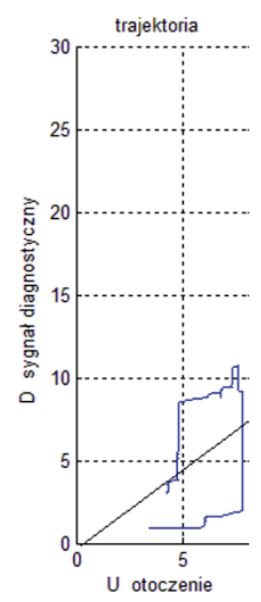

Fig. 5a. Reduced state trajectory for the experiment for test a (figs. 3a and 4a)

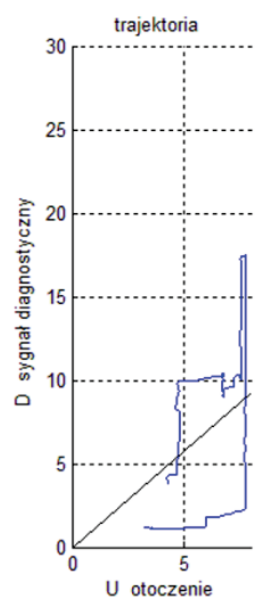

Fig. 5b. Reduced state trajectory for the experiment for test $b$ (figs. $3 b$ and $4 b$ ) 


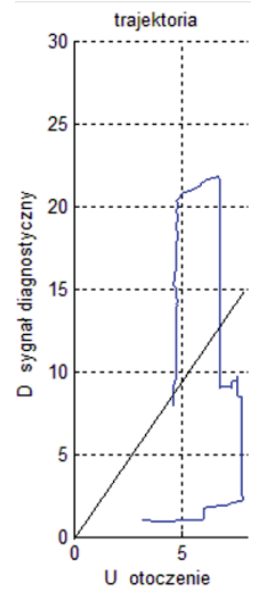

Fig. 5c. Reduced state trajectory for the experiment for test $\mathrm{c}$ (figs. $3 \mathrm{c}$ and $4 \mathrm{c}$ )

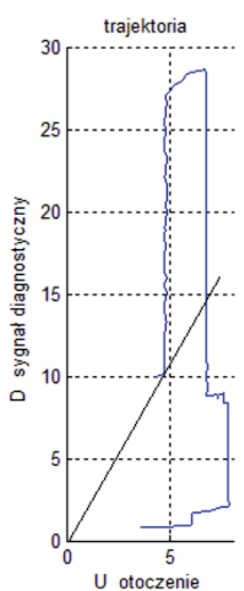

Fig. 5d. Reduced state trajectory for the experiment for test $\mathrm{d}$ (figs. $3 \mathrm{~d}$ and $4 \mathrm{~d}$ )

The results of the experiment in the form of the trajectory and statistical characteristics (figs. 5) are overlaid with a "matrix" constructed from the model calculated static characteristics (fig. 1) and trajectory (fig. 2). Then, a picture of the relationship between the $\mathrm{D}$ and $\mathrm{U}$ signals for the experiment and for the pattern (matrix) is obtained, which allows to interpret the current technical condition of the machine, which is illustrated in fig. 6 .

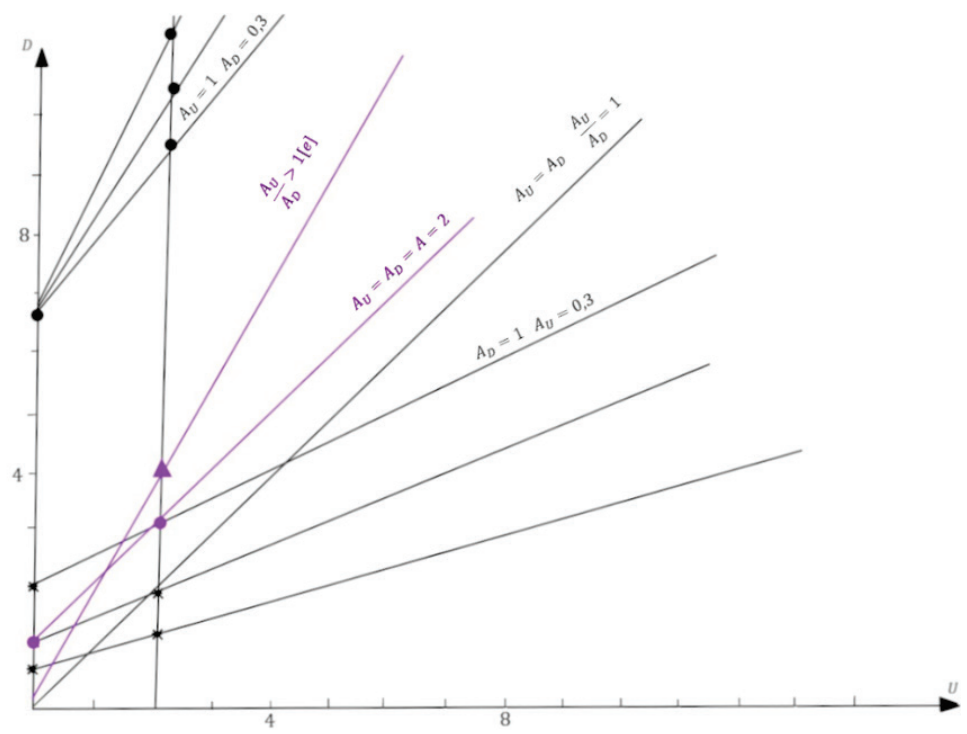

Fig. 6. The grid made of the static characteristics and model trajectories (matrix) as well as the experimental static characteristics and trajectories for the waveforms of figs. $3 \mathrm{a}$, b, c, d 
By analyzing fig. 6, we see that the time waveforms, e.g., from fig. 3a, are synthetically expressed by means of the static characteristics and trajectory. Their analysis can be performed successfully by the appropriate use of a static pattern characteristic $D=U$ and a trajectory for $A_{D}=2$ and $A_{U}=0,3$. It is shown here the excessive unstable machine wear, which can also be assessed based on the waveform of static characteristics $A_{U} / A_{D}>1$ and the path of phase trajectory near the pattern when $A_{U}$ is big, and $A_{D}$ is small.

\section{Summary}

In the machine operation process, relations between diagnostic signals $D$ and rotation speed signals $U$ are analyzed. To assess its technical condition, it is essential to determine the character of wear. It is also examined whether we have excessive wear or not. To conduct such analyses, static characteristics and machine trajectory are used. They are determined directly from the recorded waveforms of signals $D$ and $U$. Their interpretation can be efficiently made after defining the theoretical static characteristic and trajectory from coupled equations of state:

$$
\begin{aligned}
& \dot{D}=a_{D} D+b_{D} U, \\
& \dot{U}=-a_{U} U-b_{U} D
\end{aligned}
$$

for the assumed modern machine states. Assuming that $D(t)$ and $U(t)$ are constant, positive and characteristics as well as the trajectory are in the first quarter of the Cartesian coordinate system and there is no indication of singularities, then they become a sufficient premise for assessing the degree of excessive wear of the machine. Further research with the use of subsequent matrices will be helpful in the precise assessment of machine technical condition $[1,3,5]$.

\section{References}

1. Cempel C.: Teoria i inżynieria systemów. PIB, Poznań 2006.

2. Grądzki R., Lindstedt P.: Method of assessment of technical object attitude in environMent of exploitation and service conditions. Eksploatacja i niezawodność Maintenance and Reliability, Vol. 17 (1), 2015.

3. Kurowski W.: Podstawy teoretyczne komputerowego miernictwa systemów mechanicznych. Wyd. Politechniki Białostockiej, Białystok 1994.

4. Lindstedt P., Sudakowski T., Grądzki R.: Eksploatacyjna niezawodność maszyny i jej teoretyczne podstawy. ITWL, Warszawa 2016.

5. Minorsky N.: Drgania nieliniowe. PWN, Warszawa 1967. 
6. Pełczewski W.: Teoria sterowania. WNT, Warszawa 1980.

7. Kotkowski J., Rokicki E., Lindstedt P., Spychała J., Perczyński J., Karbowiak H.: Diagnostics of turbine blades, based on estimation of frequency response function. Journal of Konbin, Vol. 51, Iss. 1, 2021, DOI 10.2478/jok-2021-0022.

8. Spychała J. et al.: Sprawozdanie merytoryczne z wykonania projektu rozwojowego nr OR00010209 „Demonstrator systemu diagnozowania zespołu wirnikowego silnika odrzutowego". Załącznik do Raportu Końcowego z Projektu Rozwojowego nr OR00010209. Internal development, ITWL Warszawa 2012. 


\section{DIAGNOSTYKA PRZYPADKU WZMOŻONEGO ZUŻYCIA MASZYNY BAZUJĄCA NA MODELU ROZWOJOWYCH, PROGRESYWNYCH INTERAKCJI MIĘDZY SYGNAŁAMI ZUŻYCIA I SYGNAŁAMI UŻYTKOWYMI}

\section{Wprowadzenie}

W procesie eksploatacji maszyn (zespołów, elementów) występują dwa ściśle ze sobą powiązane zjawiska: użytkowanie (związane z jakością i intensywnością funkcjonowania maszyny, warunkami jej działania, intensywnością wykorzystania, jakością użytkowania, obsługą itp.) - generuje zbiór użytkowych (funkcjonalnych) sygnałów $U$, oraz zużywanie (powiązane ze zmianami stanu technicznego maszyny, uszkodzeniami, degradacją, zniszczeniem, zużyciem itp.) - generuje zbiór sygnałów zużywania (diagnostycznych) $D$. Procesy te (użytkowanie i zużywanie) są różnej natury fizycznej. Stąd sygnały $U$ i $D$ są dowolnymi wielkościami fizycznymi: funkcjonalnymi, defektoskopowymi, termowizyjnymi, wibroakustycznymi itp., zdeterminowanymi i probabilistycznymi. Dlatego badanie relacji między tymi sygnałami jest złożone i często w różnym stopniu ujmowane w sposób uproszczony.

W dotychczasowej praktyce eksploatacyjnej często zakłada się, że procesy te są autonomiczne. Przy takim założeniu procesy (zjawiska) użytkowania (działania) i zużywania (diagnostyczne) można opisać rozdzielnymi (niepowiązanymi) równaniami stanu $[1,2,5]$ :

$$
\begin{gathered}
\dot{U}=-a_{U} U \\
\dot{D}=a_{D} D
\end{gathered}
$$

gdzie:

$U, \dot{U}$ - kompleksowy sygnał użytkowania (działania, funkcjonowania) i jego pochodna

$a_{U} \quad$ - parametr charakteryzujący potencjał użytkowy maszyny

$D, \dot{D}$ - kompleksowy sygnał diagnostyczny (zużycia i jego pochodna)

$a_{D}$ - parametr charakteryzujący stan zużycia (degradacji) maszyny. 
Założenie autonomiczności procesów zużywania i użytkowania jest zbyt daleko idące $[3,5,6]$. Wiadomo bowiem, że sposób i intensywność użytkowania maszyny ma znaczący wpływ na szybkość zmiany jej stanu technicznego (zużycia) i odwrotnie, stan zużycia maszyny ma wpływ na jej działanie (możliwości jej użytkowania). Relacje między sygnałami działania $U$ i zużywania diagnostycznego $D$ w warunkach wzajemnych progresywnych (rozwojowych, niebezpiecznych) interakcji można opisać stosowanymi w automatyce typowymi liniowymi równaniami stanu $[2,4,5]$ :

$$
\begin{gathered}
\dot{U}=-a_{U} U-b_{U} D \\
\dot{D}=a_{D} D+b_{D} U
\end{gathered}
$$

gdzie dodatkowo:

$b_{U}$ - parametr intensywności oddziaływania stanu zużycia $D$ na stan działania $U$

$b_{D}$ - parametr intensywności oddziaływania stanu działania $U$ na stan zużycia $D$.

Analizując równania (3) i (4) można wywnioskować, że identyfikację układu opisanego uwikłanymi równaniami (3) i (4) można sprowadzić do wyznaczenia zdeterminowanych relacji między sygnałami $\{\mathrm{D}\} \mathrm{i}\{\mathrm{U}\}$ w postaci charakterystyk statycznych i trajektorii stanu oraz wartości i proporcji dotyczących parametrów $a_{U}, b_{U}, a_{D}$, $b_{D}$. W ten sposób wyznaczona zostanie potrzebna informacja do przeprowadzenia procesu diagnozowania maszyny (oceny stanu stopnia zużycia i jakości funkcjonowania maszyny).

\section{Podstawy teoretyczne do analizy równań interakcji}

Diagnozowany obiekt techniczny (maszyna) może być w różnych stanach eksploatacyjnych. Może mieć mały potencjał użytkowy (mała wartość $\left|a_{U}\right|$ ); mały stopień wrażliwości na potencjał użytkowy (mała wartość $\mathrm{b}_{\mathrm{U}}$ ). Obiekt też może mieć duży stan zużycia (duża wartość $a_{D}$ ) i duży stopień wrażliwości na warunki użytkowania i regulacji (duża wartość $b_{D}$ ). Takich kombinacji może być bardzo wiele. Stąd analiza równań (3) i (4) musi być szeroka, wszechstronna i obejmująca pełną statyczną i dynamiczną identyfikację, aktywnie wykorzystującą elementy topologii algebraicznej i rachunku wariacyjnego (kombinatoryki) bez ich jednoznacznych rozwiązań $[1,5,7]$.

\subsection{Identyfikacja statyczna obiektu opisanego równaniem progresywnej interakcji}

Wyznacza się relacje między sygnałami $D$ i $U$ dla stanów ustalonych, które charakteryzują się tym, że pochodne $\dot{D}$ i $\dot{U}$ są równe zero. Relacje $\mathrm{D}=\mathrm{f}(\mathrm{U})$ dla stanów ustalonych przedstawia się za pomocą charakterystyki statycznej. W celu wyznaczenia charakterystyki statycznej równania (3) i (4) należy stronami dodać. Ta operacja rachunku 
wariacyjnego często jest stosowana w rozwiązywaniu tego typu problemów $[1,5]$. Po dodaniu stronami otrzymuje się:

$$
\dot{U}+\dot{D}=-a_{U} U-b_{U} D+a_{D} D+b_{D} U
$$

a po uporządkowaniu:

$$
\dot{D}+b_{U} D-a_{D} D=-a_{U} U+b_{D} U-\dot{U}
$$

Przy założeniu $\dot{U}=0$ oraz $\dot{D}=0$ otrzymuje się:

$$
-a_{D} D+b_{U} D=-a_{U} U+b_{D} U
$$

i dalej:

$$
\left(a_{D}-b_{U}\right) D=\left(a_{U}-b_{D}\right) U
$$

i ostatecznie:

$$
D=\frac{a_{U}-b_{D}}{a_{D}-b_{U}} U
$$

Po wprowadzeniu $A_{U}=a_{U}-b_{D} ; A_{D}=a_{D}-b_{U}$ otrzymuje się:

$$
D=\frac{A_{U}}{A_{D}} U
$$

Ze wzoru (10) widać, że gdy $A_{U}$ duże i $A_{D}$ małe $\mathrm{A}_{\mathrm{D}}<\mathrm{A}_{\mathrm{U}}$ to charakterystyka statyczna jest bardzo stroma, a gdy $A_{U}$ małe i $A_{D}$ duże $A_{D} \gg A_{U}$ to charakterystyka jest płaska. Dla przypadku $A_{U}=A_{D}$ charakterystyka jest nachylona pod kątem $45^{\circ}$. Wtedy $\frac{A_{U}}{A_{D}}=1$.

Zatem dla przypadku $A_{U}=A_{D}$ będzie to:

$$
a_{U}-b_{D}=a_{D}-b_{U}
$$

przy czym $a_{U}>b_{D}$ i $a_{D}>b_{U}$.

I dalej:

$$
a_{U}+b_{U}=a_{D}+b_{D}
$$


Przy założeniu $b_{U}=b_{D}=b$ otrzymamy:

$$
a_{U}=a_{D}
$$

Charakterystyki statyczne bazujące na wzorze (10) przy uwzględnieniu (11), (12) i (13) przedstawiono na rys. 1 .

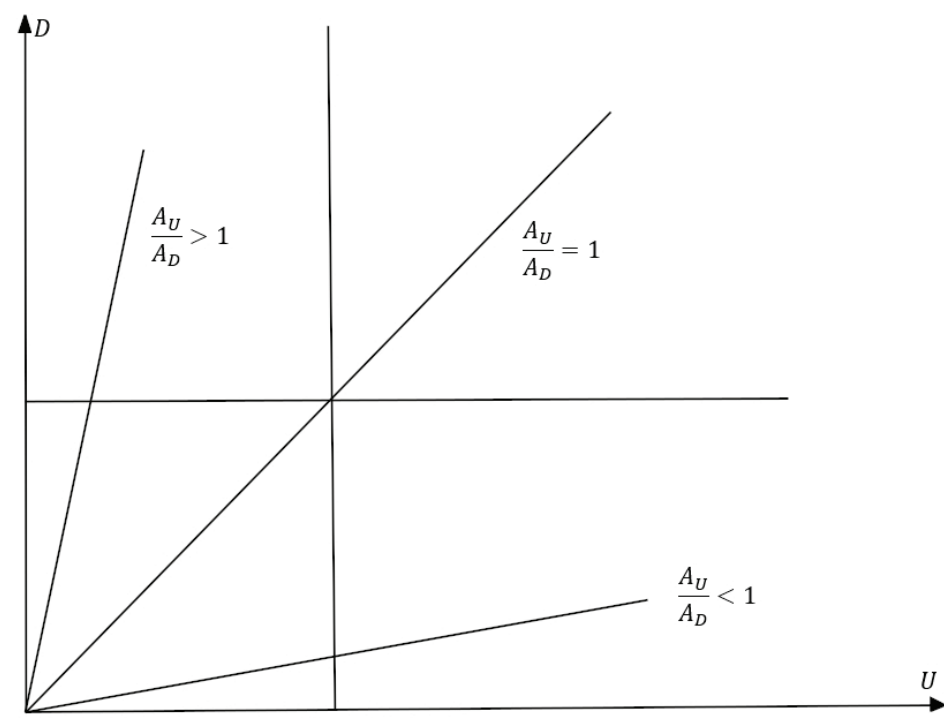

Rys. 1. Charakterystyki statyczne dla osobliwych, szczególnych relacji między parametrami $\mathrm{a}_{\mathrm{U}}$, $a_{D}, b_{U}, b_{D}$ modelu progresywnych interakcji miedzy sygnałami zużycia $D$ i sygnałami użytkowymi $U$

Proces wnioskowania diagnostycznego może zatem bazować na badaniu położenia charakterystyki statycznej wyznaczonej z bieżącego badania diagnostycznego w czasie eksploatacyjnym $\theta$ względem charakterystyk wzorcowych (odniesienia) (rys. 1). Zatem gdy $\left|A_{U}\right|$ rośnie, to charakterystyka statyczna staje się bardziej stroma, a gdy $A_{D}$ rośnie, to staje się bardziej płaska (11). Dalej, gdy $b_{D}$ maleje, to charakterystyka będzie bardziej stroma, a gdy $b_{U}$ maleje, to charakterystyka statyczna będzie bardziej płaska (9). Należy zauważyć, że w rozpatrywanym stanie eksploatacyjnym charakteryzującym się ciągłym, progresywnym procesem degradacji maszyny $a_{D}$ i $a_{U}$ zawsze rosną (stopień zużycia i stopień wykorzystania potencjału użytkowego rosną) oraz $b_{U}$ i $b_{D}$ także zawsze rosną aż do stanu: $b_{D}=a_{U}$ i $b_{U}=a_{D}$. 


\subsection{Identyfikacja dynamiczna obiektu opisanego równaniami progresywnej interakcji}

Relacja między sygnałami $D$ i $U$ może być przedstawiona jako trajektoria, którą otrzymuje się z równań (3) i (4) po wyrugowaniu czasu $t$ metodą całkowania bezpośredniego [5]. Zatem równanie (5) będące sumą równań (3) i (4) po wykonaniu odpowiednich przekształceń przyjmuje postać:

$$
\dot{U}+\dot{D}=\left(-a_{U}+b_{D}\right) U+\left(a_{D}-b_{U}\right) D
$$

Prawą stronę równania doprowadza się do postaci umożliwiającej przeprowadzenie operacji całkowania bezpośredniego (z definicji):

$$
\dot{U}+\dot{D}=\left(-a_{U}+b_{D}\right) \frac{1}{2} \dot{U}^{2}+\left(a_{D}-b_{U}\right) \frac{1}{2} \dot{D}^{2}
$$

Po scałkowaniu:

$$
U+D=\frac{1}{2}\left(-a_{U}+b_{D}\right) U^{2}+\frac{1}{2}\left(a_{D}-b_{U}\right) D^{2}
$$

Równanie (16) można doprowadzić do postaci:

$$
-\frac{1}{2}\left(a_{D}-b_{U}\right) D^{2}+D=-\frac{1}{2}\left(a_{U}-b_{D}\right) U^{2}-U
$$

i dalej:

$$
\left(a_{D}-b_{U}\right) D^{2}-2 D=\left(a_{U}-b_{D}\right) U^{2}+2 U
$$

i ostatecznie po dokonaniu podstawień $a_{D}-b_{U}=A_{D} ; a_{U}-b_{D}=A_{U}$ :

$$
A_{D} D^{2}-2 D=A_{U} U^{2}+2 U
$$

Zgodnie z zasadami topologii można ustalić metrykę dla wybranych, charakterystycznych stanów wzorcowych złożonej z trajektorii opisanych równaniem (19).

Równanie (19) można przepisać w różnych postaciach:

$$
\begin{aligned}
& \left(A_{D} D-2\right) D=A_{U} U^{2}+2 U \\
& A_{D} D^{2}-2 D=\left(A_{U} U+2\right) U
\end{aligned}
$$




$$
A_{D} D^{2}-2 D=C(U)
$$

Wyznacza się wiele przykładowych trajektorii przy różnych szczególnych założeniach. Zakłada się, że $A_{D}=A_{U}=A$.

Wtedy z równania (19) otrzymuje się:

$$
A D^{2}-2 D=\mathrm{A} U^{2}+2 U
$$

Po przekształceniach (20):

$$
\begin{gathered}
A\left(D^{2}-U^{2}\right)=2 D+2 U \\
A(D-U)(D+U)=2(D+U) \\
D-U=\frac{2}{A} \\
D=\frac{2}{A}+U
\end{gathered}
$$

Gdy dodatkowo założy się, że $A_{D}=A_{U}=A=2$, to wtedy:

$$
D=1+U
$$

Można dodatkowo założyć, że $A>2$, a następnie $A<2$. Wtedy z równania (22) otrzymuje się zbiór prostych równoległych do prostej opisanej równaniem (23). Nasuwa się pytanie jaka jest relacja między $\mathrm{D}=\mathrm{f}(\mathrm{U})$ dla $\mathrm{U}=0$, gdzie $U-$ sygnał działania.

Wtedy z równania (19a) mamy:

$$
\left(A_{D} D-2\right) D=0
$$

$\mathrm{Z}$ równania (24) otrzymujemy dwa pierwiastki:

$$
D_{1}=2 \operatorname{oraz} D_{2}=0
$$

Dla U > 0 równanie (19c) przyjmuje postać:

$$
A_{D} D^{2}-2 D-C(U)=0
$$


Dalej korzystając ze znanych wzorów na rozwiązanie równania kwadratowego:

$$
\begin{gathered}
a x^{2}+b x+c=0 \\
\Delta=b^{2}-4 a c \\
x_{1,2}=\frac{-b \pm \sqrt{\Delta}}{2 a}
\end{gathered}
$$

$Z$ równania (25) dla każdego założonego $U>0$ wyznacza się dwa pierwiastki:

$$
\begin{aligned}
& D_{1}=\frac{1}{A_{D}}\left(1+\sqrt{1+A_{D} A_{U} U^{2}+2 A_{D} U}\right) \\
& D_{2}=\frac{1}{A_{D}}\left(1-\sqrt{1+A_{D} A_{U} U^{2}+2 A_{D} U}\right)
\end{aligned}
$$

Ponieważ z eksperymentu [8] wynika, że sygnały $D$ i $U$ są dodatnie, to analizie podlega tylko pierwiastek $D_{1}$ (pierwiastek $D_{2}$ jest zawsze ujemny). Następnie można wyznaczyć dodatkowe charakterystyczne punkty trajektorii przy odpowiednich kolejnych założeniach, np. że $A_{D}$ jest kilka razy większe od $A_{U}$, a następnie, że $A_{U}$ jest kilka razy większe od $A_{D}$, a to pozwala uzyskać dodatkową, konkretną informację przydatną do interpretacji wzorów (22) i (23), w których to wykorzystano założenie $A_{D}=A_{U}$.

Zatem można założyć, że:

dla $U=0 ; A_{U}<A_{D} ; A_{U}=0,3$, to z równania (26) mamy:

$$
D_{1}=\frac{1}{A_{D}}(1+\sqrt{1})=\frac{2}{A_{D}}
$$

dla $U=0,1 ; A_{U}<A_{D} ; A_{U}=0,3$, to z równania (26) mamy:

$$
D_{1}=\frac{1}{A_{D}}\left(1+\sqrt{1+0,203 A_{D}}\right)
$$

dla $U=1 ; A_{U}<A_{D} ; A_{U}=0,3$, to z równania (26) mamy:

$$
D_{1}=\frac{1}{A_{D}}\left(1+\sqrt{1+2,3 A_{D}}\right)
$$

dla $U=2 ; A_{U}<A_{D} ; A_{U}=0,3$, to z równania (26) mamy: 


$$
D_{1}=\frac{1}{A_{D}}\left(1+\sqrt{1+5,2 A_{D}}\right)
$$

dla $U=4 ; A_{U}<A_{D} ; A_{U}=0,3$, to z równania (26) mamy:

$$
D_{1}=\frac{1}{A_{D}}\left(1+\sqrt{1+12,8 A_{D}}\right)
$$

dla $U=8 ; A_{U}<A_{D} ; A_{U}=0,3$, to z równania (26) mamy:

$$
D_{1}=\frac{1}{A_{D}}\left(1+\sqrt{1+35,2 A_{D}}\right)
$$

Dalej przyjmując wartości dla $A_{D}=1,2,4$ odpowiednio większych od wartości parametru $A_{U}=0,3$ otrzymamy punkty wybranych poszukiwanych wzorcowych trajektorii odniesienia. Punkty tych trajektorii przedstawiono w tab. 1.

Tabela 1

Punkty trajektorii odniesienia $D=f(U)$ dla różnych przypadków

\begin{tabular}{|c|c|c|c|c|c|c|}
\hline$A_{D}$ & 0 & 0,1 & 1 & 2 & 4 & 8 \\
\hline 1 & 2 & 2,1 & 2,82 & 3,49 & 4,72 & 7,02 \\
\hline 2 & 1 & 1,1 & 1,69 & 2,19 & 3,08 & 4,73 \\
\hline 4 & 0,5 & 0,59 & 1,05 & 1,42 & 2,06 & 3,23 \\
\hline
\end{tabular}

Następnie badana jest zmiana $D_{1}=f(U)$ dla różnych wartości $A_{U}=1,2,4$ odpowiednio większych od $A_{D}=0,3$, czyli dla przypadku, gdy spełniony jest warunek $A_{U}>A_{D}$ przy spełnieniu warunku, że $\mathrm{a}_{\mathrm{D}}>0 ; \mathrm{a}_{\mathrm{U}}>0$.

Zatem można zapisać, że:

dla $U=0 ; A_{D}<A_{U} ; A_{D}=0,3$, to z równania (26) otrzymuje się:

$$
D_{1}=3,333(1+\sqrt{1+0})=6,666
$$

dla $U=0,1 ; A_{D}<A_{U} ; A_{D}=0,3$, to z równania (26) otrzymuje się:

$$
D_{1}=3,333\left(1+\sqrt{1,06+0,003 A_{U}}\right)
$$

dla $U=1 ; A_{D}<A_{U} ; A_{D}=0,3$, to z równania (26) otrzymuje się:

$$
D_{1}=3,333\left(1+\sqrt{1,6+0,3 A_{U}}\right)
$$


dla $U=2 ; A_{D}<A_{U} ; A_{D}=0,3$, to z równania (26) otrzymuje się:

$$
D_{1}=3,333\left(1+\sqrt{2,2+1,2 A_{U}}\right)
$$

dla $U=4 ; A_{D}<A_{U} ; A_{D}=0,3$, to z równania (26) otrzymuje się:

$$
D_{1}=3,333\left(1+\sqrt{3,4+4,8 A_{U}}\right)
$$

dla $U=8 ; A_{D}<A_{U} ; A_{D}=0,3$, to z równania (26) otrzymuje się:

$$
D_{1}=3,333\left(1+\sqrt{5,8+19,2 A_{U}}\right)
$$

Dalej przyjmując wartości dla $A_{U}=1,2,4$ odpowiednio większych od parametru $A_{D}=0,3$ otrzymuje się punkty wybranych poszukiwanych wzorcowych trajektorii odniesienia.

Punkty tych trajektorii przedstawiono w tab. 2.

Tabela 2

Punkty trajektorii odniesienia $D=f(U)$ dla różnych przypadków $A_{U}>A_{D}$, gdy $A_{D}=0,3$

\begin{tabular}{|c|c|c|c|c|c|c|}
\hline$A_{U}$ & 0 & 0,1 & 1 & 2 & 4 & 8 \\
\hline 1 & 6,666 & 6,766 & 7,93 & 9,47 & 12,87 & 20,0 \\
\hline 2 & 6,666 & 6,772 & 8,27 & 10,47 & 15,37 & 25,5 \\
\hline 4 & 6,666 & 6,782 & 8,899 & 12,17 & 19,16 & 33,63 \\
\hline
\end{tabular}

Na podstawie danych z tabel 1 i 2 wykreślono charakterystyczne trajektorie dla rozwiązań równań (3) i (4) - rys. 2. 


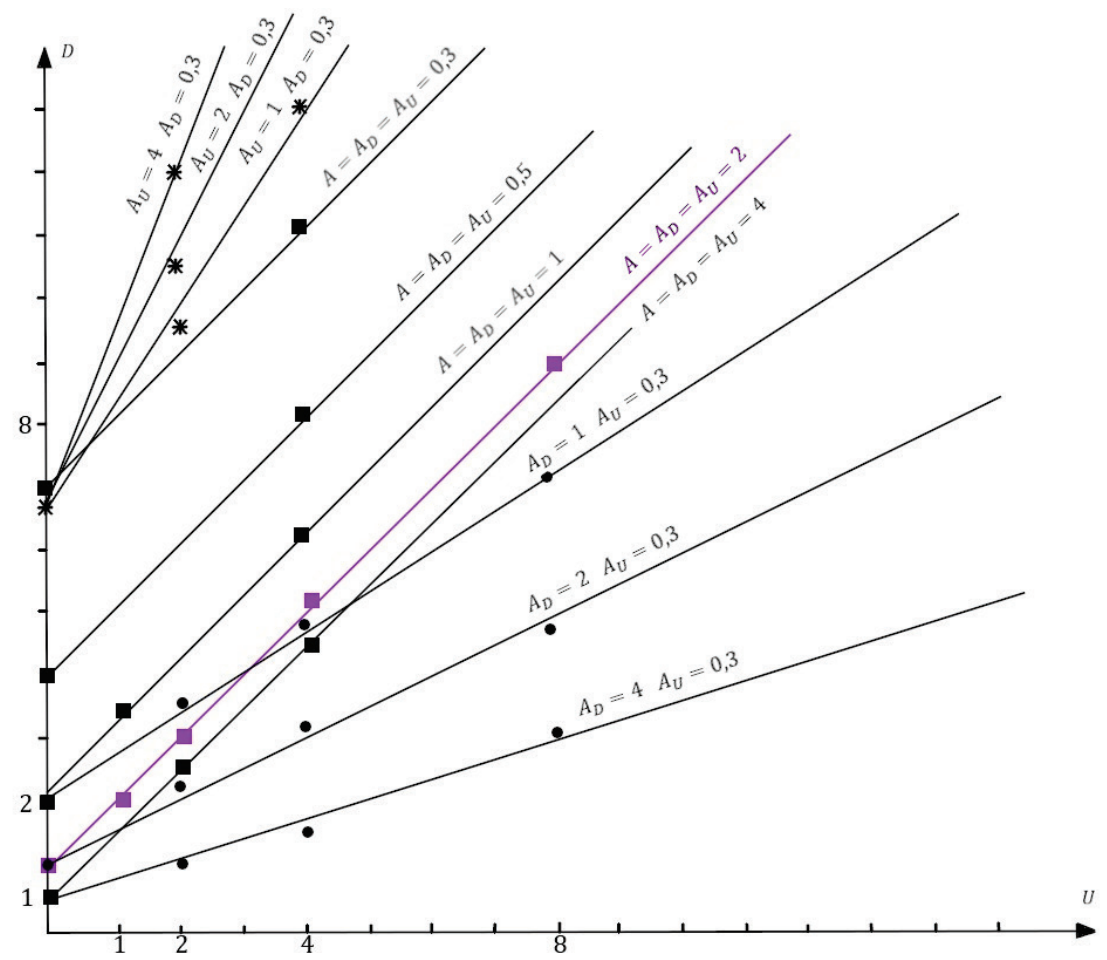

Rys. 2. Trajektoria odniesienia $D=f(U)$ dla szczególnych przypadków relacji między parametrami $A_{U}$ i $A_{D}: A_{U}>A_{D}, A_{U}=A_{D}, A_{U}<A_{D}$

Trajektorie $D=f(U)$ (rys. 2) są różne dla różnych, w tym szczególnych przypadków relacji między parametrami $A_{U}$ i $A_{D}$. Są to wiązki linii stromych, które mają wspólny początek $\mathrm{D}=\frac{2}{\mathrm{~A}_{\mathrm{D}}}$ dla $\mathrm{U}=0$, przy czym $A_{D}=$ const i $A_{D}<A_{U}\left(A_{D}=0,3 ; A_{U}=1,2,4\right)$ albo wiązki linii równoległych opisanych równaniem $D=\frac{2}{A_{D}}+U$ o różnym początku $D=\frac{2}{A}$ przy czym dla $\mathrm{A}_{\mathrm{U}}=\mathrm{A}_{\mathrm{D}}=\mathrm{A}=2$ otrzymamy $\mathrm{D}=1+\mathrm{U}$ o początku $D=1$, mogą to też być wiązki linii płaskich, które mają różny początek, a dla $U=0$ mają wartość $\frac{2}{A_{D}}$ dla $A_{U}=0,3$. Widać zatem, że dla $\mathrm{U}=0$ można ocenić $A_{D}$ i dalej z przebiegu trajektorii także $A_{U}$, czyli określić stan zużycia obiektu.

\section{Matryca diagnozowania}

Matrycę diagnozowania tworzy się $\mathrm{z}$ założonych wzorcowych charakterystyk statycznych i trajektorii stanu wyznaczonych dla jednoznacznie zidentyfikowanego sposobu zużywania opisanego dla niego dopasowanym modelem interakcji. Zatem 
charakterystyki statyczne z rys. 1 i trajektorie z rys. 2 są matrycą diagnostyczną pozwalającą interpretować przebiegi sygnałów $D$ i $U$ przy założeniu, że zostały one wyznaczone dla maszyny, która znalazła się w stanie wzmożonego zużycia. Matryca może być z dobrym skutkiem wykorzystana w procesie wnioskowania diagnostycznego.

Eksperymentalnie dla maszyny (wału silnika) wyznaczono sygnały $D$ (wartość skuteczna precesji wału silnika odczytana $\mathrm{z}$ eksperymentu) i $U$ (obr/min), które przedstawiono na rys. 3a, b, c, d [8].
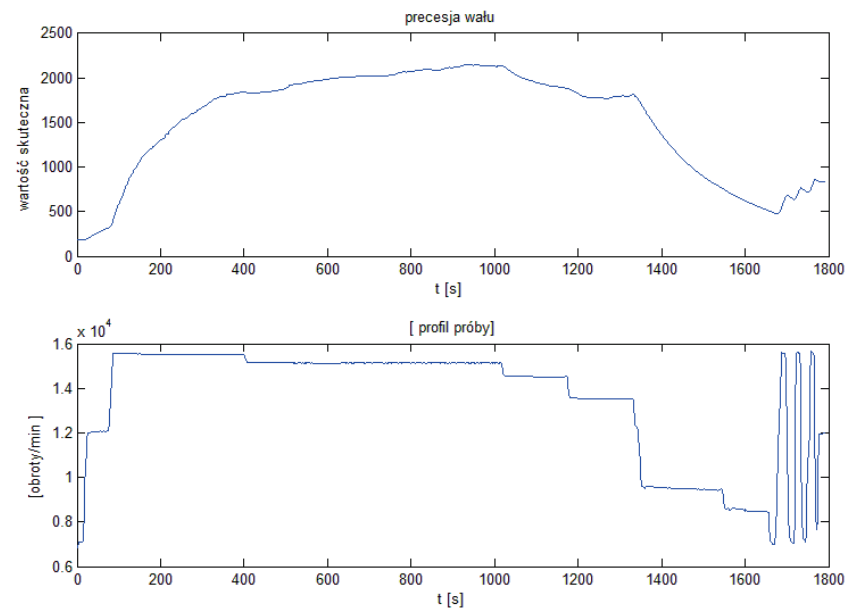

Rys. 3a. Profil próby a - zmierzone parametry prędkości obrotowej wału silnika lotniczego $U$ i wartości skutecznej precesji wału $D$ w eksperymencie diagnostycznym
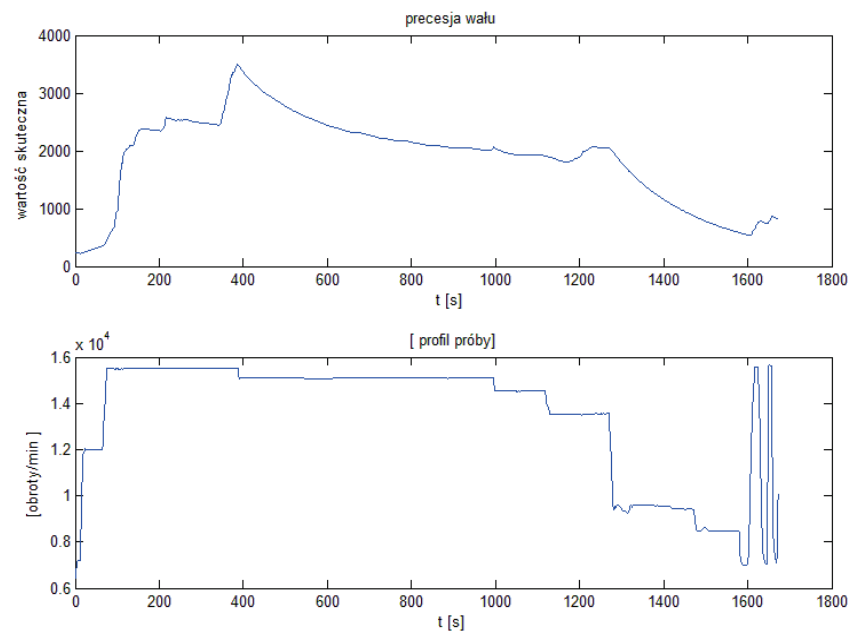

Rys. 3b. Profil próby $\mathrm{b}$ - zmierzone parametry prędkości obrotowej wału silnika lotniczego $U$ i wartości skutecznej precesji wału $D$ w eksperymencie diagnostycznym 

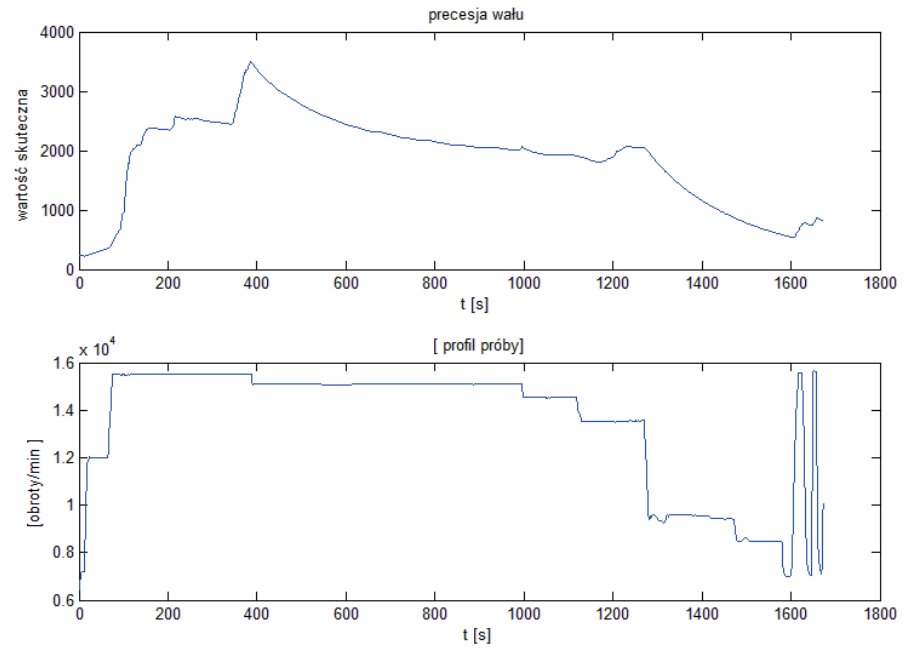

Rys. 3c. Profil próby c - zmierzone parametry prędkości obrotowej wału silnika lotniczego $U$ i wartości skutecznej precesji wału $D$ w eksperymencie diagnostycznym
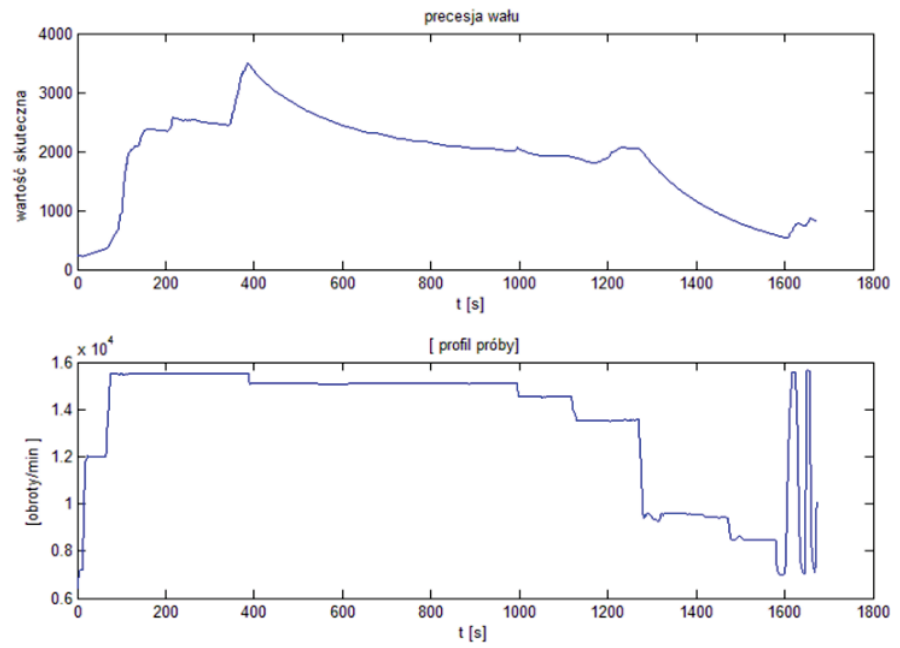

Rys. 3d. Profil próby d - zmierzone parametry prędkości obrotowej wału silnika lotniczego $U$ i wartości skutecznej precesji wału $D$ w eksperymencie diagnostycznym

Wyniki eksperymentu (rys. 3a, b, c, d) po wyrugowaniu czasu przedstawiono na rys. $4 \mathrm{a}, \mathrm{b}, \mathrm{c}, \mathrm{d}$. 


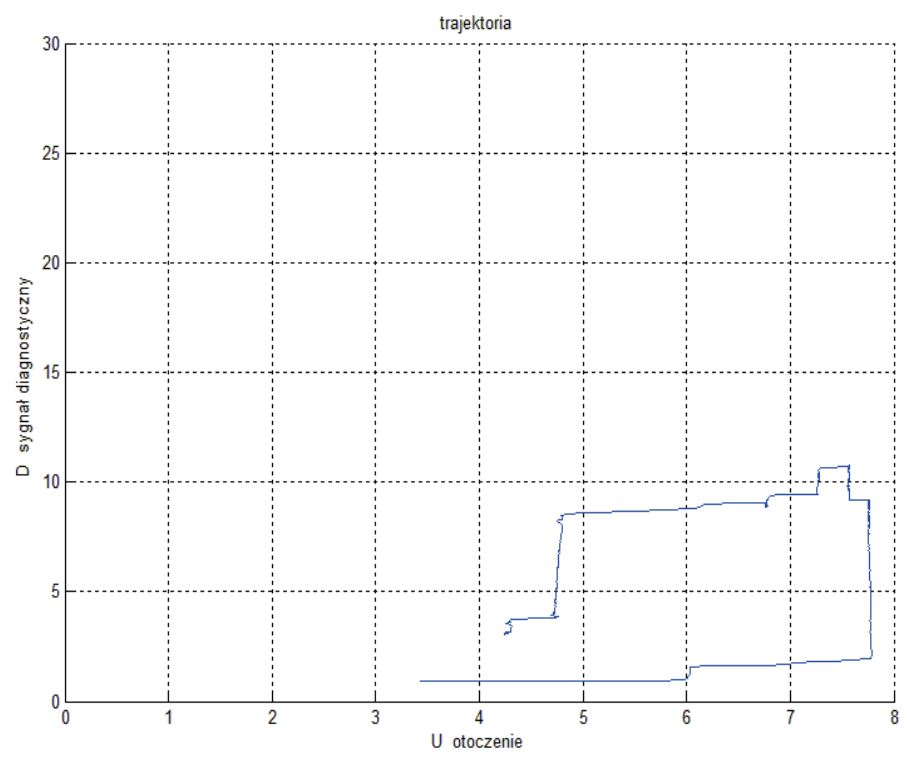

Rys. 4a. Trajektoria relacji między sygnałem diagnostycznym $D$, a sygnałem otoczenia $U$ z eksperymentu z próby a (rys. 3a)

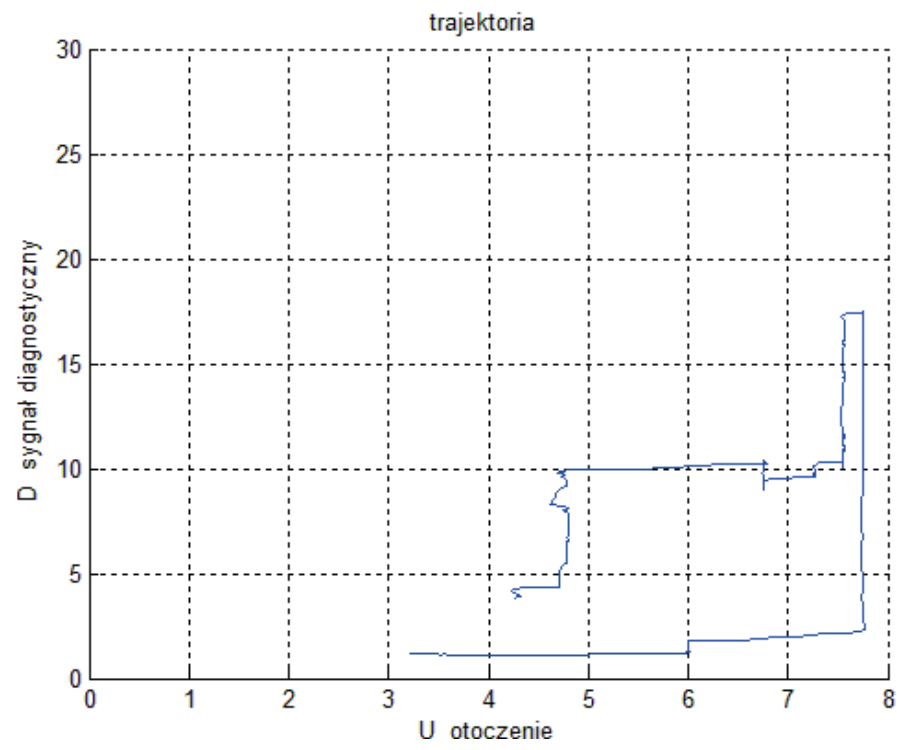

Rys. 4b. Trajektoria relacji między sygnałem diagnostycznym $D$, a sygnałem otoczenia $U$ z eksperymentu z próby b (rys. 3b) 


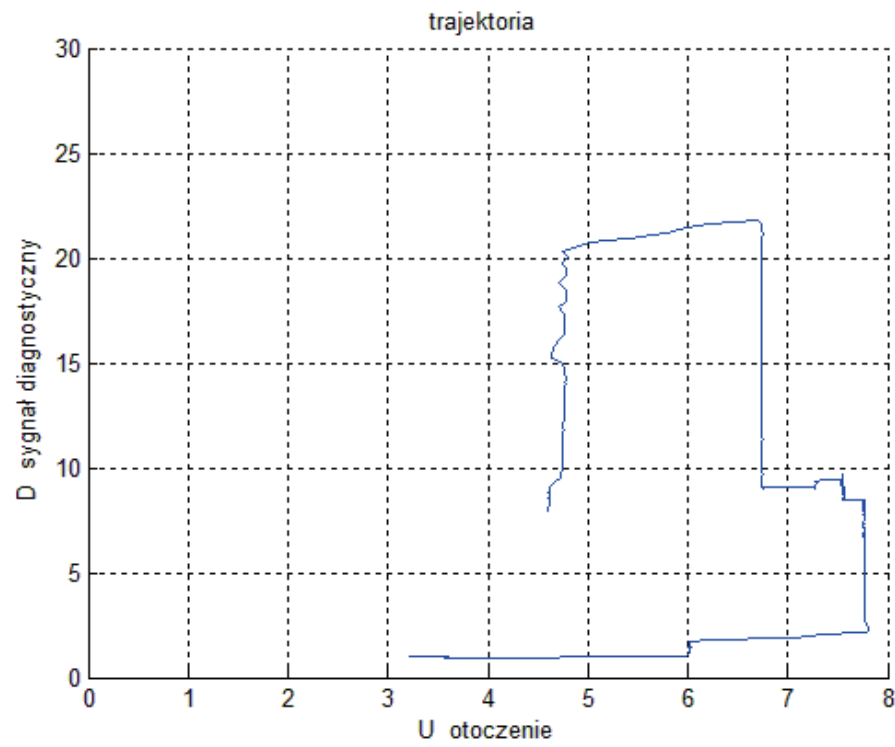

Rys. 4c. Trajektoria relacji między sygnałem diagnostycznym $D$, a sygnałem otoczenia $U$ z eksperymentu z próby c (rys. 3c)

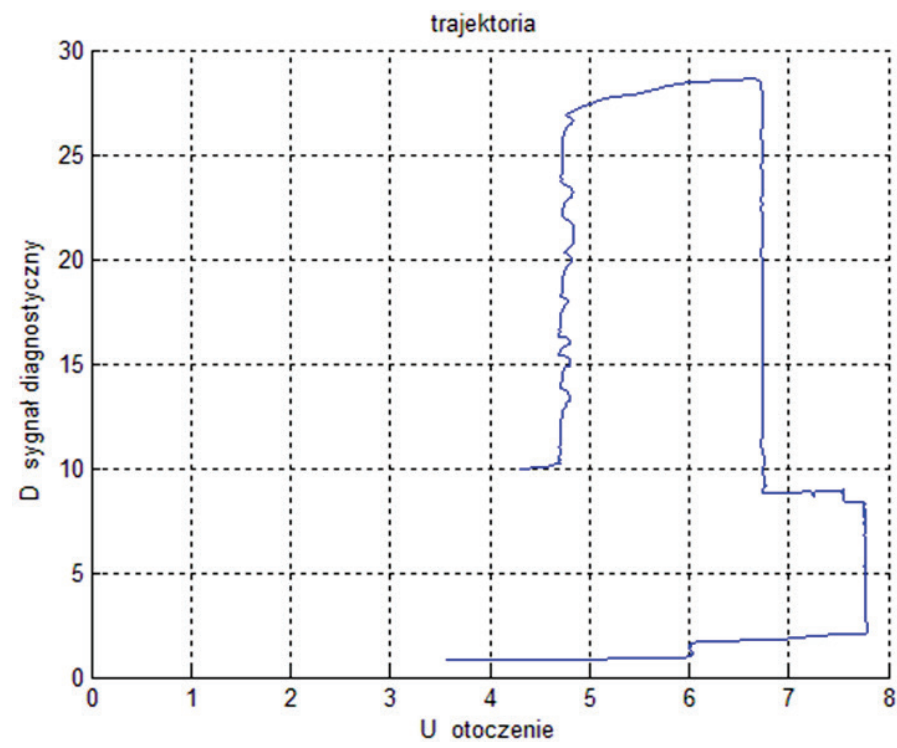

Rys. 4d. Trajektoria relacji między sygnałem diagnostycznym $D$, a sygnałem otoczenia $U$ $\mathrm{z}$ eksperymentu z próby $\mathrm{d}$ (rys. $3 \mathrm{~d}$ )

Skalę pomiaru $D$ i $U$ doprowadza się do skali sygnałów, która została zastosowana w matrycy. Zatem, gdy na rys. 3 jest, że $D$ zmienia się od $0 \div 6000$, a $U$ zmienia się 
od $6 \div 1,6 * 10^{4}$, to po uwzględnieniu skali matrycy (tabele 1 i 2 ): $D$ zmienia się od $0 \div 30$, a $U$ od $0 \div 8$. Wtedy przebiegi z rys. 3 i po wyrugowaniu czasu (rys. 4 ) przyjmą postać taką jak na rys. 5. Są to trajektorie stanu i charakterystyki statyczne, które jednoznacznie opisują stany ustalone i nieustalone pracy maszyny.

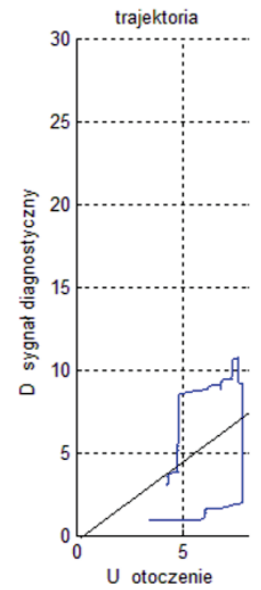

Fig. 5a. Zredukowana trajektoria stanu dla eksperymentu dla próby a (rys. $3 \mathrm{a}$ i $4 a)$

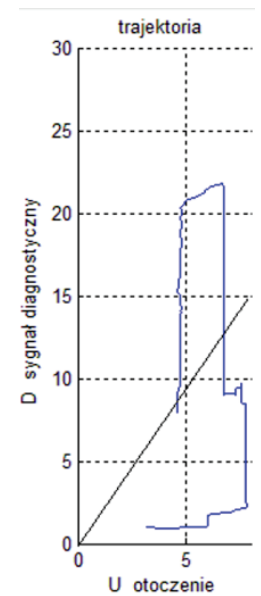

Fig. 5c. Zredukowana trajektoria stanu dla eksperymentu dla próby c (rys. 3c i 4c)

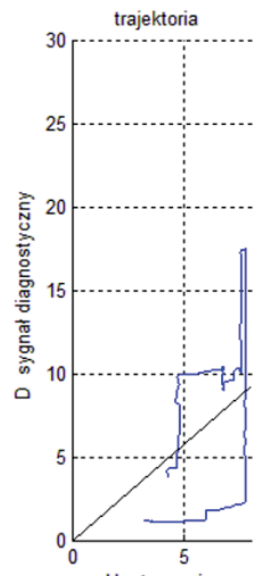

Fig. 5b. Zredukowana trajektoria stanu dla eksperymentu dla próby b (rys. $3 \mathrm{~b}$ i $4 b)$

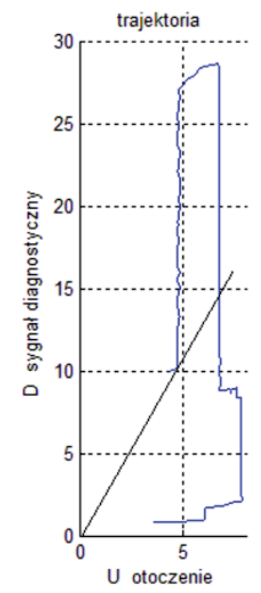

Fig. 5d. Zredukowana trajektoria stanu dla eksperymentu dla próby d (rys. $3 \mathrm{~d}$ i $4 d$ ) 
Na wyniki eksperymentu sprowadzone do trajektorii i charakterystyki statystycznej (rys. 5) nakłada się matrycę skonstruowaną z wzorcowych obliczonych charakterystyk statycznych (rys. 1) i trajektorii (rys. 2). Wtedy otrzymuje się obraz relacji między sygnałami $D$ i $U$ dla eksperymentu i dla wzorca (matrycy) pozwalający interpretować aktualny stan techniczny maszyny, co zilustrowano na rys. 6.

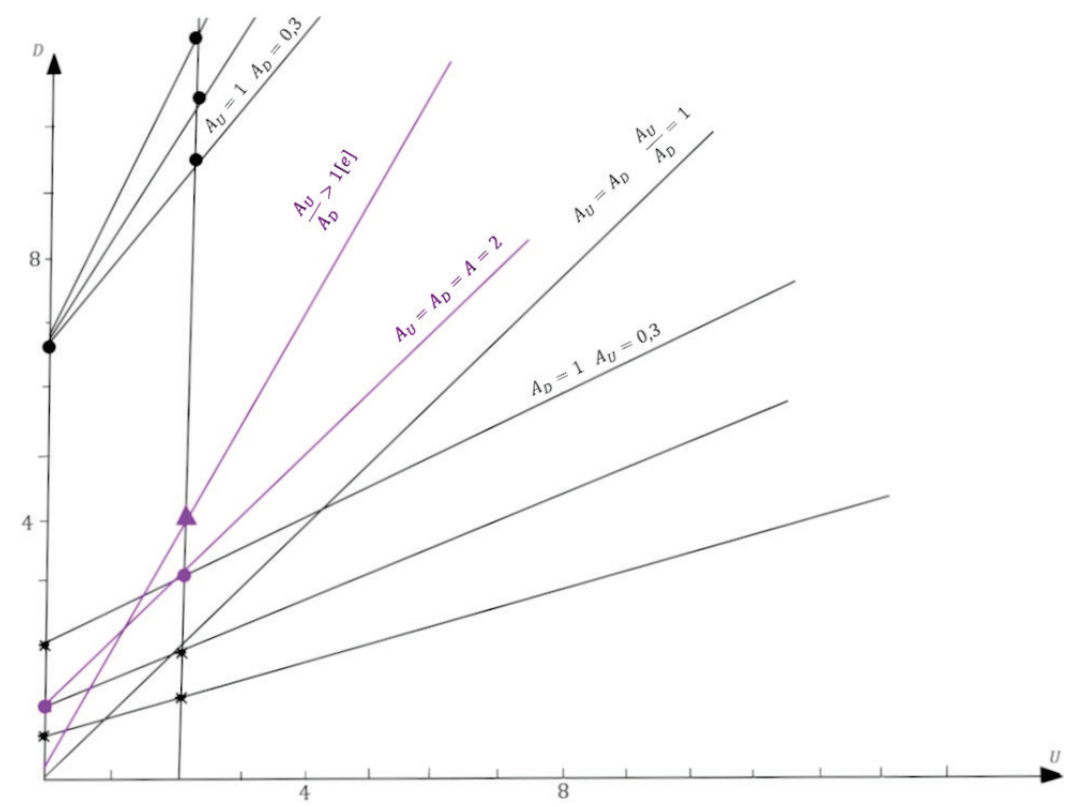

Rys. 6. Siatka utworzona $z$ charakterystyki statycznej i trajektorii wzorcowych (matryca) oraz eksperymentalne charakterystyki statyczne i trajektorie dla przebiegów z rys. 3a, b, c, d

Analizując rys. 6, można zauważyć, że przebiegi czasowe, np. z rys. 3a są syntetycznie wyrażone za pomocą charakterystyki statycznej i trajektorii stanu. Ich analiza może być z dobrym skutkiem przeprowadzona poprzez odpowiednie wykorzystanie wzorcowej charakterystyki statycznej $D=U$ i trajektorii dla $A_{D}=2$ i $A_{U}=0,3$. Widać tu, że mamy przypadek wzmożonego, niestatecznego zużycia maszyny co także można ocenić na podstawie przebiegu charakterystyki statycznej $A_{D} / A_{U}>1$ i przebiegu trajektorii fazowej w pobliżu wzorca, gdy $A_{U}$ jest duże, a $A_{D}$ małe.

\section{Podsumowanie}

W procesie eksploatacji maszyny badane są relacje między sygnałami zużycia $D$ i sygnałami użytkowymi $U$. W celu oceny jej stanu technicznego bardzo ważną, wstępną informacją jest określenie charakteru zużywania. Bada się, czy w danej chwili jest stan 
wzmożonego zużycia, czy też tego stanu nie ma. Do przeprowadzenia takich analiz należy wykorzystać charakterystykę statyczną i trajektorię maszyny, które wyznacza się bezpośrednio z zarejestrowanych przebiegów sygnałów $D$ i $U$. Ich interpretacja może być skutecznie przeprowadzona po wyznaczeniu teoretycznych charakterystyk statycznych i trajektorii, ze sprzężonych równań stanu:

$$
\begin{gathered}
\dot{D}=a_{D} D+b_{D} U, \\
\dot{U}=-a_{U} U-b_{U} D
\end{gathered}
$$

dla założonych wzorcowych stanów maszyny. Przy założeniu, że $D(t)$ i $U(t)$ są ciągłe i dodatnie oraz charakterystyki i trajektoria znajdą się w pierwszej ćwiartce układu kartezjańskiego i nie występują przesłanki wskazujące na istnienie punktów osobliwych, to wtedy stają się one wystarczającą przesłanką do oceny stopnia występującego wzmożonego charakteru zużywania się maszyny. Dalsze badania z wykorzystaniem kolejnych matryc pozwolą doprowadzić do precyzyjniej oceny stanu technicznego maszyny $[1,3,5]$.

\section{Literatura}

1. Cempel C.: Teoria i inżynieria systemów. PIB, Poznań 2006.

2. Grądzki R., Lindstedt P.: Method of assessment of technical object attitude in environMent of exploitation and service conditions. Eksploatacja i niezawodność Maintenance and Reliability, Vol. 17 (1), 2015.

3. Kurowski W.: Podstawy teoretyczne komputerowego miernictwa systemów mechanicznych. Wyd. Politechniki Białostockiej, Białystok 1994.

4. Lindstedt P., Sudakowski T., Grądzki R.: Eksploatacyjna niezawodność maszyny i jej teoretyczne podstawy. ITWL, Warszawa 2016.

5. Minorsky N.: Drgania nieliniowe. PWN, Warszawa 1967.

6. Pełczewski W.: Teoria sterowania. WNT, Warszawa 1980.

7. Kotkowski J., Rokicki E., Lindstedt P., Spychała J., Perczyński J., Karbowiak H.: Diagnostics of turbine blades, based on estimation of frequency response function. Journal of Konbin, Vol. 51, Iss. 1, 2021, DOI 10.2478/jok-2021-0022.

8. Spychała J. i in.: Sprawozdanie merytoryczne z wykonania projektu rozwojowego nr OR00010209, „Demonstrator systemu diagnozowania zespołu wirnikowego silnika odrzutowego". Załącznik do Raportu Końcowego z Projektu Rozwojowego nr OR00010209. Opracowanie wewnętrzne ITWL, Warszawa 2012. 